KULTURA - MEDIA - TEOLOGIA

ISSN 2081-89-71

$2020 \mathrm{nr} 43$, s. $102-137$

Mateusz Flont

Uniwersytet Jagielloński w Krakowie

\title{
Aksjologia audiowizualności (cz. 1). Rozważania teoretyków i praktyków podczas seminarium w Instytucie Dziennikarstwa, Mediów i Komunikacji Społecznej Uniwersytetu Jagiellońskiego (15.03.2019)
}

\author{
Axiology of audiovisualness (part 1). \\ Considerations of theoreticians and practitioners during \\ the seminar at the Institute of Journalism, Media and Social \\ Communication Jagiellonian University (15/03/2019)
}

\begin{abstract}
ABSTRAKT
Poniższy tekst jest sprawozdaniem z seminarium naukowego, które odbyło się na Uniwersytecie Jagiellońskim. Poruszano na nim tematy wartości, które są przekazywane w mediach, filmach, literaturze, języku i szeroko pojętej sztuce. Oprócz przedstawienia referatów umieszczono również zapis dyskusji, które odbywały się między każdym wystąpieniem.
\end{abstract}

SŁOWA KLUCZOWE:

wartości, audiowizualność, media, obraz rzeczywistości

\begin{abstract}
The following text is a report from a scientific seminar that took place at the Jagiellonian University. It touched upon themes of values that are transmitted in the media, films, literature, language and broadly understood art. In addition to presenting the papers, there was also a presentation of discussions that took place between each speech.
\end{abstract}

\section{KEYWORDS:}

values, audiovisualness, media, image of reality

\footnotetext{
O
} rganizatorami ogólnopolskiego seminarium naukowego „Aksjologia audiowizualności”, które odbyło się 15. marca 2019 roku w Instytucie Dziennikarstwa, Mediów i Komunikacji Społecznej w budynku Wydziału Zarządzania i Komunikacji Społecznej Uniwersytetu Jagiellońskiego w Krakowie, byli prof. dr hab. Robert Cieślak z Uniwersytetu Warszawskiego (Katedra Antropologii Mediów), 
prof. UJ dr hab. Wojciech Kajtoch (IDMiKS) oraz prof. zw. dr hab. Jacek Dąbała (Instytut Dziennikarstwa i Komunikacji Społecznej Katolickiego Uniwersytetu Lubelskiego), który przywitał gości, zaznaczając, że powodem do spotkania się były kwestie wartościowania we współczesnym świecie i oceny dzieła medialnego, stanowiące wyzwanie dla badaczy i dlatego należy im się przyjrzeć z różnych pozycji - i wykształcenia, i afiliacji.

W seminarium wzięli udział, oprócz już wymienionych, prof. dr hab. Filip Bajon (PWSFTviT), ks. prof. UPJP2 dr hab. Michał Dróżdż, prof. UWr dr hab. Anna Gemra, red. Jarosław Gugała (Polsat), prof. UJ dr hab. Małgorzata Lisowska-Magdziarz (IDMiKS), prof. UKSW dr hab. Grzegorz Łęcicki.

Niniejszy tekst jest sprawozdaniem z seminarium „Aksjologia audiowizualności”, zawierającym zarówno zredagowane i autoryzowane referaty prelegentów, jak i zapis dyskusji, które między tymi wykładami się odbywały. Z uwagi na objętość tekstu, sprawozdanie podzielono na dwie części.

\section{***}

\section{Grzegorz Łęcicki, „,Paradygmaty aksjologii audiowizualnych przekazów medialnych w perspektywie teologii środków społecznego przekazu. Wyzwania teoretyczne i praktyczne"}

Reprezentuje wąską dziedzinę, która sytuuje się na pograniczu nauk o mediach i teologii, a mianowicie teologię mediów. W swoich badaniach staram się analizować przekazy audiowizualne, a konkretnie filmy i seriale. Zacznę od pytania: Jaką piramidę wartości spróbowalibyśmy ułożyć we współczesnym świecie? Czy byłaby to piramida „przewróconych wartości”? Zwróćmy uwagę na to, że specyfiką mediów audiowizualnych jest ich różnorodność, która determinuje sposób formułowania badawczego problemu i analizy krytycznej. Za swój przewodnik przyjmuję estetykę Romana Ingardena i Marii Gołaszewskiej. Myślę, żeby zastosować te zasady fenomenologiczne do badania przekazów audiowizualnych. To jest fundament polskiego myślenia o mediach audiowizualnych na najbardziej ontycznym poziomie.

Zastanawiając się nad właściwym ustaleniem hierarchii aksjologicznej odnoszącej się do wszystkich mediów audiowizualnych, stwierdzam, że może być to znana jeszcze ze starożytności triada wartości prawda, dobro, piękno. Ale czy 
można użyć tej triady zarówno podczas analizy wiadomości telewizyjnych, jak i filmu fabularnego? Z jednej strony jest to duży poziom ogólności. Intuicyjnie widać, że triada ta będzie się „rozjeżdżać”, gdyż w wiadomościach interesować nas będzie przede wszystkim to, czy program telewizyjny jako przekaz audiowizualny jest prawdziwy. A czy przy dziele artystycznym podstawowy jest element prawdy? On się wiąże oczywiście również z dobrem, ale czy tu nie odgrywa większej roli kwestia piękna? To jest dla mnie problem intelektualny w poradzeniu sobie z kategorią piękna, dlatego że możemy definiować różnie piękno, mamy stanowiska i teologów, i filozofów (chrześcijańskich, katolickich), mamy też laickie rozwiązania i propozycje. Z drugiej strony wiemy, patrząc bardzo subiektywnie w tym momencie, że jeśli chodzi o samą kategorię piękna: nie ładne co ładne, tylko co się komu podoba. Przeżywanie piękna też może się zmieniać. Przykładowo, ten sam film może podlegać zupełnie innej ocenie, tzn. wcześniej się może nie podobać, a po pewnym czasie dzięki różnym lekturom, dojrzałości życiowej i doświadczeniom, a także znajomości samego dzieła, mogą się w umyślę uruchomić zupełnie inne "filtry” niż wcześniej. Wówczas człowiek może dostrzec inne wartości, a zatem następuje jakby ewolucji postrzegania piękna w przekazie audiowizualnym.

Wracając jednak do kwestii badawczych, teolog mediów zastanawia się nad tym, czy jest możliwe stanięcie obok i kształtowanie jakiejś hierarchii wartości, która pasowałaby do różnych przekazów? Jako teolog odwołam się do najbardziej ogólnych norm w postaci Dekalogu i wartości ewangelicznych; one obowiązują wszystkich chrześcijan, zawsze i wszędzie. Z kolei w regułach zakonnych nie oddziela się Ewangelii i Dekalogu od życia chrześcijańskiego, jest tak przykładowo w regule benedyktyńskiej, ignacjańskiej czy franciszkańskiej - tu normy są już bardzo szczegółowe.

Metodę badawczą widziałby w sposób następujący: z jednej strony badacz miałby do dyspozycji klasyczną triadę wartości, z drugiej zaś zestawy wartości szczegółowych, które pozwoliłyby odbiorcy odróżnić sposoby wartościowania byłyby to zatem osobne metody do analizy programów informacyjnych, dzieł artystycznych, filmów dokumentalnych, migawek na YouTubie, wideoklipów itd. Ta różnorodność nie powodowałaby chaosu aksjologicznego, gdyż odwołanie się do fundamentu byłoby rodzajem bezpiecznika, który potrafiłby utrzymać w ryzach zarówno uczonego, który bada te przekazy, jak i tych, którzy je odbierają. 


\section{Dyskusja po referacie prof. Grzegorza Łęcickiego}

Filip Bajon: Widzę pewien zamysł ustawienia tej rozmowy, że będziemy rozmawiać o efekcie, o filmie, wideoklipie, audycji telewizyjnej - i tutaj mamy ten poziom aksjologiczny. Natomiast ja nie myślę o dziele, tylko ja myślę, jak do tego dzieła się dochodzi i o elementach, które tworzą audiowizualność. Czy one podlegają aksjologii, czy nie. Pan profesor mówił o różnych systemach aksjologicznych. Tutaj może powstać pewien bałagan, bo to kalos kagatos (ideał greckiego wychowania - przyp. MF) może nie wyczerpać wszystkich możliwości... W stosunku do wideoklipu czy do YouTube’a w ogólne zastanawiałbym się, czy audiowizualność można poszerzać w nieskończoność. Generalnie dojdziemy do tego, że wszystko jest audiowizualne w tej chwili, nawet jeżeli nie wie, że jest audiowizualne, bo widać go i śpiewa. W ogóle sprecyzowałbym pewien postulat, czy zakres naszej penetracji ograniczamy, czy nie. Bo to są dwie różne postawy.

Jacek Dąbała: A to świetne pytanie, ja bym chciał się przyłączyć. Jak rozumiem, czy są granice audiowizualności?

Wojciech Kajtoch: Kwestia granic audiowizualności - moim zdaniem granicą tą jest rzeczywistość, bo każda sztuka ma charakter mimetyczny, czyli jeżeli odejdziemy całkowicie od rzeczywistości, to byśmy tę audiowizualność zatracili. Problem polega na tym, że przecież od rzeczywistości odejść się nie da, więc nie ma granic, bo wszystko to, co istnieje, może być oceniane z punktu widzenia wzroku, choćby nawet wyobraźni wzrokowej...

Filip Bajon: Ograniczenie poprzez formę.

Wojciech Kajtoch: Oczywiście, bo przecież tak samo jak nie ma rzeczy, które by nie były rzeczywiste, tak samo nie ma rzeczy, które by nie były audiowizualne i które by nie miały formy. Bo jeśli coś nie ma formy, to tego czegoś po prostu nie ma. Więc można powiedzieć, że problem ograniczenia badań jest problemem niejako praktycznym - na co my możemy sobie pozwolić, a co na zawsze przed nami pozostanie ukryte. Chyba że zajdzie jakiś wielki skok w naszych możliwościach poznawczych i to rozumianych nie tylko jako możliwości poznawcze jednostki.

A teraz do właściwego referatu. Prawda, dobro, piękno - nie są to wartości przez wszystkich uznawane za jednakowe, zwłaszcza odbija się to w momencie, kiedy mówimy o prawdzie: prawda jako zgodność z rzeczywistością i prawda jako racja - to jest to rozróżnienie podstawowe. Z drugiej strony to, co było powiedziane, bardzo mi przypomina teorię aktu mowy czy aktu komunikacji. Wiadomo że akt mowy nie zajdzie, jeżeli wszystkie funkcje mowy nie będą spełnione. Trzy 
główne akty: powiadamianie o rzeczywistości, wyrażanie emocji i wpływanie na emocje. W znanym schemacie Jacobsona piękno ma też swoje miejsce. Te funkcje są spełniane $\mathrm{w}$ różnej proporcji. Na tym zróżnicowaniu proporcji opiera się np. podział na rodzaje dziennikarskie, gdyż czym innym będzie reportaż, a czym innym felieton czy informacja - odwoływać się będą do innych funkcji mowy. Zwrócił na to uwagę prof. Walery Pisarek w książce „Frekwencja wyrazów w prasie” z 1972 r., w której pokazał, czym różnią się od siebie wiadomości, komentarze i reportaże, jeśli spojrzymy na nie z punktu widzenia ilości występowania części mowy. Wychodziło $\mathrm{z}$ tego, że dane gatunki w różny sposób te funkcje realizują, jest to ciągłe, nie ma ostrych granic.

Teraz uważam, że mimo wszystko istnieją pewne możliwości zakłócenia tych proporcji i te możliwości konstytuują pewne nurty, czy to w sztuce, czy w literaturze itd. W momencie kiedy pojawia się zbyt duża dążność w kierunku prawdy, no to wtedy mamy naturalizm, czyli dzieje się tak, że prawda przechodzi w zaprzeczenie siebie samej. W momencie kiedy mamy zbytnie ciążenie w kierunku dobra, to wtedy mamy utwory tendencyjne, bo każdy uważa, że to jest dobrem, co on za dobro uważa. Natomiast z pięknem jest tak, że kiedy nie ma piękna, wtedy rzecz jest niemożliwa do odebrania, bo jest nieskończenie obrzydliwa. Jeżeli mamy do czynienia z czymś pozbawionym piękna, wtedy nas odrzuca, nie jesteśmy w stanie tego przyjąć.

Natomiast jeżeli mamy do czynienia z pięknem przede wszystkim, to wtedy sprawia to przyjemność naszym zmysłom i naszemu umysłowi, mogłaby być to np. abstrakcja. Jej twórca abstrahuje od wszystkiego, od czego można abstrahować.

Sądzę, że w tej chwili media audiowizualne wyraźnie ciągną w stronę takiego nasycenia pięknem, bo obraz może być piękny, a człowiek zawsze się stara, żeby tego piękna było jak najwięcej. Klasycznym przykładem jest oczywiście film, gdzie są całe sceny, które przede wszystkim zachwycają. Piękno jest obecne również w literaturze, fotografii, w zasadzie wszędzie - nawet informacja może być piękna, bo może być skomponowana w sposób np. symetryczny.

Przykładowo, kiedy oglądam z żoną telewizję, wtedy małżonka np. narzeka, że rzecz jest nierealistyczna albo zupełnie tak nie jest, albo że widać głupią propagandę czy coś w tym rodzaju. Ja wtedy mówię, no tak, ale to jest ładne po prostu. Więc wydaje mi się, że to piękno jest taką omastą, która nam w tej chwili pomaga wszystko przełykać. Można powiedzieć, że nas tak pociesza w tej rzeczywistości, w której żyjemy i że jest wyznacznikiem dzisiejszej epoki to, że temu, 
kto robi media, przede wszystkim zależy też na tym, żeby to, co zostało zrobione było ładne. Chociażby był propagandzistą... Wiadomo, że jeżeli coś jest brzydkie, to tego nikt nie łyknie i w związku z tym ta propaganda pójdzie na marne. Ja bym był za pięknem.

Oczywiście istnieje także pytanie, skąd to piękno się bierze. To jest pytanie, na które raczej odpowiedzieć nie mogę, jest np. dla teologa.

Małgorzata Lisowska-Magdziarz: Ja trochę inaczej, od strony semiotyka, na to patrzę. Istnieje jednak różnica pomiędzy wielomodalną naturą wszelkiej komunikacji a audiowizualnością.

Do badania audiowizualności potrzebujemy operacjonalizacji, określenia granic tego, co badamy. W przeciwnym razie nasza dyskusja dotyczyłaby aksjologii, nie komunikowania. Zgadzam się więc z panem, gdy chodzi o znaczenie formy, a to dlatego że za terminem audiowizualność stoi pewna konwencja semantyczna, która wiąże to pojęcie z zapośredniczeniem technologicznym. Jeśli ją uwzględnimy, to rzeczywiście możemy mówić o kryteriach, wskazujących na określone sposoby używania różnych środków semiotycznych - właśnie z powodu tego, że zapośredniczenie technologiczne wymaga formy, wymaga ograniczenia i przypisania wartości przekazowi o konkretnych granicach i konkretnym zasobie trybów. Tryby semiotyczne nie są przypadkowym zbiorem środków, tylko zawsze powstają w wyniku długotrwałego społecznego użytkowania środków semiotycznych. Z tego zawsze wynika pewien poziom wewnętrznego uporządkowania. Na przykład - nie patrzymy w sposób przypadkowy i nieprzewidywalny; to, jak patrzymy, jest wyuczone i uwarunkowane konwencjami kulturalnymi.

Używanie środków wizualnych też nie jest przypadkowe, tylko najpierw jest idea formy i pewnego zakresu afordancji trybu wizualnego, czyli tego, co przy jego pomocy chcemy zakomunikować, co można zakomunikować, czego się natomiast zrobić nie da lub do czego lepiej nadają się inne tryby. Dlatego w semiotyce wielomodalnej mówi się o transmodalności, czyli o sposobie, w który przekaz sformułowany przy pomocy wybranego zasobu semiotycznego ktoś inny próbuje wyrazić przy pomocy innego zasobu. Przykładami mogą tu być muzyka programowa albo adaptacja filmowa dzieła literackiego.

W związku tym to zapośredniczenie technologiczne komunikatów audiowizualnych (ważne zwłaszcza w dzisiejszym zmediatyzowanym świecie) to punkt wyjścia do refleksji nad jego formami. Chodziłoby o wydzielenie tego, co sztuczne, kulturowe, z całego świata doznań wizualnych i audialnych. Doznania te można 
oczywiście także wartościować. W takim wypadku jednak, jeśli oddzielimy to od zagadnienia formy, będą to ogólne rozważania aksjologiczne, nie zaś aksjologia przekazu audiowizualnego.

Jarosław Gugała: Nie jestem naukowcem, tylko praktykiem i chciałbym trochę rozluźnić nasze ramy. Bo kiedy pan profesor wspomina o triadzie prawda, dobro, piękno, to przypomina mi się Artur Rubinstein. Kiedyś zapytano go, kto jego zdaniem jest dobry pianista. Rubinstein, który był praktykiem, a nie teoretykiem, zastanowił się chwilę i powiedział tak: „Moim zdaniem dobry pianista to jest taki pianista, który umie grać długo, głośno i ładnie". Ja przytaczam te anegdotę, bo ona pokazuję pewną bezradność tego rodzaju ogólnych terminów do badania czegokolwiek i wydaje mi się, że prawda, dobro, piękno czy inne aksjomaty istnieją tylko wtedy, gdy jesteśmy w stanie je odebrać. A jesteśmy w stanie je odebrać tylko w zakresie, w którym jesteśmy do tego uprawnieni czy też uwrażliwieni.

Pan profesor mówił o filmach, które się panu kiedyś nie podobały, ale dojrzał pan do nich. Gdybyśmy człowiekowi wychowanemu w epoce Chopina puścili muzykę Rachmaninowa, to nie byłaby dla niego piękna. Gdyby Chopin mógł wysłuchać Rachmaninowa, to by pewnie uznał, że to w ogóle nie jest sztuka, że to w ogóle nie jest piękne. Ponieważ prawdopodobnie nie był dojrzały do odebrania tego rodzaju muzyki.

Mnie się wydaje, że wyjściem z tego być może byłoby jednak posługiwanie się terminologią funkcjonalną. I określanie, że pięknem jest to, co dla konkretnego odbiorcy może pełnić rolę piękna lub wywoływać w nim estetyczne wrażenia. I wówczas nie mamy jednej definicji piękna, tylko definicja piękna zależy od przygotowania każdego odbiorcy, który sam ją definiuje po swojemu.

Podczas jazdy samochodem słucham muzyki klasycznej. Czasami jacyś nieszczęśnicy wsiadają ze mną do tego samochodu. I większość ludzi, kiedy próbuję słuchać muzyki eksperymentalnej lub klasycznej, natychmiast szuka nerwowo wyłącznika, żeby tego nie słuchać. Jakby diabła zobaczyli. Świadczy to o tym, że oni akurat nie są w stanie w tym czymś, co we mnie budzi wrażenia estetyczne, odnaleźć sensu i piękna. Bo nie są do tego odbioru przygotowani.

Mówi pani o transmodalności - przy tej okazji, istnieje takie ciekawe zjawisko, rodzaj pomieszania zmysłów, to się nazywa synestezja. Będąc osobą wrażliwą na dźwięki, jednocześnie jestem w stanie te dźwięki namalować, bo one mają dla mnie mają bardzo konkretne barwy. Do tego stopnia, że nawet różnym imionom i nazwom własnym potrafię przypisać konkretne barwy. Podobnie jest 
z muzycznymi tonacjami. Podobno kilka procent populacji doświadcza synestezji. I ta transmodalności w tym sensie może być użyteczną kategorią. To pokazuje, jak skomplikowaną rzeczą jest praktyczne wykorzystanie ogólnych klasycznych terminów.

I wracam znowu do tego Rubinsteina. Jak on mówi, że dobry pianista to jest taki, który umie grać długo, no to znowu trzeba zdefiniować, co to znaczy długo. Jak mówi, że głośno, no to ja rozumiem, że on się odnosi do tego, że na fortepianie uzyskuje się głośność nie przy pomocy siły fizycznej, tylko odpowiedniego dotknięcia klawiszy, czyli techniki. Ładnie - znów wracamy do kategorii piękna. Dla Chopina to, co grał Rachmaninow, prawdopodobnie nie byłoby ładne, ponieważ to łamało zasady, które on, w swoim czasie, znał i wyznawał. Może się mylę, może byłoby tak, że Chopin wysłuchawszy Rachmaninowa, powiedziałby, że nigdy więcej nie usiądzie przy fortepianie, bo to jest tak wspaniałe i wirtuozerskie, że on nigdy nie byłby w stanie osiągnąć tego poziomu wykonawczego.

Utwory muzyczne są skomponowane w ramach pewnych systemów wartości. W ramach pewnego instrumentarium charakterystycznego dla każdej epoki. I jeżeli funkcjonalnie popatrzymy z punktu widzenia każdego odbiorcy, który definiuje na swój użytek każde pojęcie w aksjologii, no to dopiero wówczas mamy szansę zobaczyć kawałek prawdy. Natomiast nie wiem, czy stosowanie zbyt szerokich pojęć wymaga bardzo dokładnego zdefiniowania, albo analizy z punktu widzenia psychologii odbioru dzieła artystycznego. Dlatego że inaczej to wszystko po prostu nic nie znaczy. To jest takie trochę macanie w próżni.

Jacek Dąbała: Czy to jest pytanie do pana profesora?

Jarosław Gugała: To są moje refleksje odnośnie do tego, co prof. Łęcicki powiedział. Natomiast prof. Kajtoch powiedział chyba, że coś, co nie ma piękna nie może istnieć...

Wojciech Kajtoch: Jest odrzucone, jest tak obrzydliwe, że nie możemy tego znieść.

Jarosław Gugała: Myślę w tym momencie o tym, że jednak zaprzeczenie piękna trwa krótko, dlatego że Grochowiak i turpiści szukali piękna tam, gdzie go teoretycznie nie było. Pokazali nam drogę, że jednak to piękno istnieje, ale istnieje wtedy, kiedy my jesteśmy dojrzali i przygotowani do odbioru tej wartości w prezentowanej nam formie.

Wojciech Kajtoch: To znaczy, że można je tam znaleźć, bo ono tam jest, tylko że jest przesłonięte pozorami obrzydlistwa. Jednak to są tylko pozory, bo przecież 
wiersze Grochowiaka są czasami wręcz wzruszające. Natomiast chodzi o to, żeby nie było piękna w ogóle, żeby brzydota nie była tylko pozorem. Istotą. I wtedy uważam, że jest to niezgodne z naturą ludzką.

Jarosław Gugała: I jeszcze odniesienie do tej triady. Dla mnie, jako praktyka, najważniejsza jest w niej prawda. Pan profesor wskazał słusznie, że piękno może być bardzo różnie rozumiane - prawda również. To nie jest tak, że istnieje jedna ogólna kategoria, że coś jest prawdą. Ta prawda jest tak samo skomplikowana i tak samo trudna do uchwycenia, i wieloraka, że również jest bardzo skomplikowaną kategorią.

I teraz zastosowanie $\mathrm{w}$ dzisiejszym medioznawstwie, np. poszukiwanie wartości poprzez analizy źródeł, np. dochodzenie, czy wywodzące się z Talmudu przykazanie Boże, że nie będziesz dawał fałszywego świadectwa przeciwko bliźniemu swemu, jest bardzo trudne i złudne. Jeśli nie mamy się kręcić cały czas w kręgu tej samej niemożliwości metodologicznej, no to musimy znaleźć na to jakiś sposób. Moim zdaniem ważne jest, żeby z badań medioznawczych korzystać potem w praktyce. Żebym ja, chcąc być lepszym dziennikarzem, znalazł gdzieś źródło tej „lepszości” w dziennikarstwie w teoretycznych rozważaniach albo w badaniach medioznawczych. Żeby one nie były li tylko akademicką dysputą na jakimś tam seminarium, tylko żeby wynikało z nich też coś, co można objąć rozumem i zastosować potem w praktyce.

Niestety jesteśmy coraz mniej przygotowani do odbierania wartości. W związku z powyższym zakres piękna i innych wartości się bardzo redukuje. Ponieważ jesteśmy wszyscy przebodźcowani, mamy problem z wyselekcjonowaniem w tym wszystkim tego, co istotne. Kończy się na tym, że wchodzimy w świat tego, co dzisiaj się nazywa mediami tożsamościowymi - a one działają na zasadzie „ta osoba jest mądra, która myśli tak, jak my”. Co jest po prostu bardzo niebezpieczne, dlatego że oddala nas to od wartości, o których tutaj rozmawiamy...

Anna Gemra: Myślę, że chodzi tu o kilka różnych spraw. Pierwszą z nich jest ta, o której rozmawiamy, czyli audiowizualność. Pamiętam książkę Noëla Carrolla Filozofia horroru. Carroll pisał o „art-grozie”, czyli o czymś, co jest wykreowane. Myślę, że to jest granica audiowizualności: między tym, co wykreowane („sztuczne”), a tym, co istniejące („rzeczywiste”).

Druga sprawa przewija się właściwie we wszystkich wypowiedziach. Mówimy o prawdzie, pięknie i tym podobnych zagadnieniach. I mówimy o tych kategoriach także z punktu widzenia odbiorców, a nie tylko tych, którzy tworzą. 
Nasuwa się w związku z tym na myśl kilka rzeczy. Po pierwsze, jeśli chodzi o odbiorców tekstów kultury popularnej, to są oni w stanie przyjąć za prawdę zasadniczo tylko to, do czego i tak byli wcześniej przekonani (to jest dopowiedzenie do głosu pana redaktora Gugały). Nie da się więc im przekazać prawdy, bo nie można przekazać prawdy komuś, kto i tak nie będzie chciał jej przyjąć. Taka publiczność akceptuje tylko tekst, w którym jest to, co chce usłyszeć, co zgadza się z jej poglądami.

Natomiast co do piękna: odwołam się tu do Oscara Wilde‘a, który powiedział, że twórca nie ma żadnego wpływu na to, co odbiorca zrobi z jego dziełem, także jeśli chodzi o estetykę. I to, co my uznamy za piękne, dla publiczności może piękne nie być. Tu się drogi nadawcy (twórcy) i odbiorcy kompletnie rozchodzą. Ten ostatni w procesie interpretacji robi z tekstem, co chce. To jest też kwestia aktualizacji odbioru, jego zależności od konkretnej chwili, konkretnego momentu w życiu, o czym mówił pan profesor Kajtoch: raz będę akceptować jakieś teksty kultury, nawet się nimi fascynować, a innym razem, w innym momencie życia w odniesieniu do tych samych tekstów mogę stwierdzić, że są okropne i dziwić się, jak ja to mogłam oglądać czy czytać. Interpretacja, odbiór zależą ode mnie w każdej chwili.

Natomiast co do mediów tożsamościowych, wygląda to tak (w mojej opinii), że akceptuje się tego, kto myśli tak jak ja. Nie zaakceptuję na swojej stronie np. facebookowej osób myślących inaczej, ponieważ ich spojrzenie na świat jest niezgodne z moim, a zatem fałszywe. Jeśli zaś chodzi o kwestię piękna, to chciałabym przypomnieć o patostreamingu, który ma obecnie ogromną i zafascynowaną nim publiczność. Jak do takiego zjawiska zastosować kategorie piękna, prawdy i inne podobne? Jaki klucz estetyczny, etyczny zastosować w interpretacji?

Grzegorz Łęcicki: Jestem wdzięczny za wszystkie państwa uwagi, dlatego że mój referat był dosyć subiektywny.

W temacie swojego wystąpienia, jeśli chodzi o taką metodologię, rzeczywiście zawarłem przekazy audiowizualne, medialne. Audiowizualność potraktowałem szeroko, tak jak ja się zajmuję przekazami medialnymi. Cieszę się, że to, co powiedziałem, wywołało takie echo, dlatego że to jest też poszukiwanie. To jest też moje pytanie - to, co państwo sformułowali, ten subiektywizm przekazu, bo z jednej strony uczymy dziennikarzy o tym, co to jest prawda, dobro, piękno, mamy definicje klasyczne, ale $\mathrm{z}$ drugiej strony mamy tyle prawd, ilu ludzi. Tylu fascynatów piękna czy pseudo-piękna ilu ludzi. 
Dlatego wyzwanie, którym się stało to wystąpienie na dzisiejszym spotkaniu, potraktowałem jako pewną zapowiedź refleksji i próbę odnalezienia oraz lepszego naświetlenia tej bardzo złożonej rzeczywistości. Próbę szukania jakiegoś uniwersalnego przewodnika i określenia takich punktów odniesienia, które pozwolą na lepsze sprecyzowanie i uściślenie norm badawczych, odnoszących się do rozmaitych przekazów medialnych. Bo tak jak państwo powiedzieli, zarówno prawda, dobro, piękno mogą być różnie postrzegane. Odwołanie się do klasycznej triady wartości w naszym kręgu kulturowym jest oczywistym fundamentem i punktem odniesienia, i okazało się twórczą inspiracją naszej dyskusji. Natomiast rzeczywiście potrzebujemy głębszego namysłu i różnorakich naświetleń, żeby z jednej strony udało nam się pogodzić obiektywizm twórcy, który ma przecież jakąś swoją intencję i wizję dzieła, przekazu medialnego, jak np. reżyser, który tworzy film i chciałby coś przekazać, z subiektywnym odbiorem widza, który czasem uważniej coś ogląda czy słucha wiadomości, a czasem mniej. Czasem się z tym zgadza, a czasem się z tym nie zgadza.

Czy istnieje możliwość stworzenia modelu jakieś systematyzacji aksjologicznej wobec rozmaitości przekazów audiowizualnych, ich bogactwa, różnorodności gatunków? Spotkaliśmy się, by także o tym podyskutować. Bardzo państwu dziękuję za wszystkie krytyczne uwagi i refleksje; jest to dla mnie istotny materiał do przemyślenia. Cieszę się, że mogłem zaprezentować swoje refleksje w takim środowisku.

***

\section{Małgorzata Lisowska-Magdziarz, „Polskie »obrazy sztandarowe« a pamięć kulturalna Polaków"}

Na początku chciałabym zwrócić uwagę na aksjologiczny wymiar obrazów oraz na projekt empiryczny, który przygotowuje wraz z grupą badawczą, a dotyczy on tytułowych „obrazów sztandarowych".

Rozpocznę od anegdoty. Raz na pięć lat mamy takie wydarzenie kulturalne, które jest dla nas jak kamień w strumieniu, zmienia bieg naszego myślenia, powoduje, że zaczynamy inaczej patrzeć na różne sprawy. W moim wypadku takim kamieniem było ostatnio obejrzenie wystawy z okazji 250-lecia letnich salonów sztuki w Royal Academy w Londynie. Zamysł tych wystaw był taki, że miały one pokazywać to, co $\mathrm{w}$ danym momencie w brytyjskich sztukach pięknych najlepsze 
i najpiękniejsze; wszystko to, co Anglicy uznawali za najważniejsze dzieła sztuki w danym roku. Te wystawy odbywały się nieprzerwanie przez 250 lat, i nawet wojny w tym nie przeszkodziły. Ponieważ jednak nabór dzieł na doroczne wystawy był otwarty, więc z czasem letnie salony Royal Academy przestały pokazywać to, co najlepsze artystycznie, zaczęły natomiast pokazywać to, co się w danym momencie Anglikom najbardziej podobało lub budziło sensację polityczną czy obyczajową. Jubileuszowa wystawa latem 2018 roku została zorganizowana w taki sposób, że sześciu wybitnych angielskich artystów i/lub kuratorów dostało prawo wybrania z zachowanych zasobów Royal Academy z tych 250 lat wszystkiego, co uznają za warte pokazania, nie tylko ze względów artystycznych, lecz także z powodów historycznych, obyczajowych, politycznych lub sentymentalnych, i połączenia tego w wybrany przez siebie sposób. Dlatego też obok (bardzo zróżnicowanej jakości) obrazów i rzeźb na wystawie znalazły się plakaty, instalacje, projekcje multimedialne, makiety architektoniczne, przedmioty użytku codziennego, hafty czy patchworki [referat był zilustrowany prezentacją multimedialną, zwierającą wiele przykładów, na których omówienie brak miejsca w niniejszym sprawozdaniu - przyp. M.F.]. Doświadczenie jest zdumiewające i przerażające. Gigantyczny tłum ludzi krąży po tych salach, od natłoku wrażeń wizualnych i mieszanych emocji boli głowa. Żeby wszystko obejrzeć, trzeba spędzić w tym tłumie co najmniej cztery godziny. Nic dziwnego, że na środku jednej z sal stoi bar z wódką... Co tam można było zobaczyć? Wielkiej sztuki tam niemal nie było. Widać było natomiast Zeitgeist, ducha epoki. Dla medioznawcy niesłychanie ciekawe było także to, jak bardzo ten duch epoki od 250 lat karmi się ikonografią mediów z danego czasu, ikonografią polityczną i popkulturową. Wyraża w ten sposób nie tylko estetykę, ale jakby wizualny charakter danego momentu.

Co ciekawe, w Polsce coś takiego również miało miejsce. Mówię o wystawie „Polaków portret własny” (wystawa otwarta 8 października 1979 roku w Muzeum Narodowym w Krakowie), która wyrażała ducha różnych epok w Polsce i Zeitgeist czasu, gdy została zorganizowana. Była to jednak wystawa przygotowana przez kuratora artystycznego, który wybierał dzieła wybitne. Oryginalnym pomysłem było w tej wystawie to, że na jej końcu było lustro i każdy ze zwiedzających mógł w nim zobaczyć własne odbicie - portret współczesnego Polaka. Jednak gust ludowy czy popularny niemal nie został na nią dopuszczony. Natomiast było widać, że Zeitgeist, smak epoki, tkanka historii, pamięć wizualna w tych portretach się odbijała. Od czerwca 2017 do stycznia 2018 roku w Krakowie 
odbyła się podobna, raczej nieudana wystawa pt. „Dziedzictwo” w Muzeum Narodowym.

Opisane wystawy zainspirowały projekt empirycznego zbadania pamięci wizualnej współczesnych Polaków. W zachodniej teorii wizualności jest trend badań nad sztuką wyrażającą pamięć lub charakter epoki - Zeitgeist art. Jednocześnie pojęcie utorowało sobie już chyba drogę do języka potocznego. Mój 19-letni syn pokazał mi pewien teledysk i mówi: wiesz, to jest Zeistgeist art. Zdziwiłam się, jak też to pojęcie znalazło się w słowniku dziewiętnastolatka. Okazało się, że młodzież używa tego terminu dla opisania teledysków o buntowniczej treści społecznej, zmontowanych z fragmentów filmów dokumentalnych i przekazów medialnych.

W Londynie skończył się też niedawno pokaz słynnej instalacji Christiana Marclaya „The Clock” - 24-godzinnego montażu maleńkich fragmentów zaczerpniętych z całej sztuki filmowej XX wieku, pokazujących tarcze i wyświetlacze zegarów. Dostajemy w ten sposób metonimię całego stulecia, i jest to hipnotyzujące doświadczenie. Dla mnie to był drugi kamień w strumieniu, zmieniający bieg moich myśli o pamięci i obrazie. Powstaje bowiem pytanie, jakie obrazy, kadry z filmów, przedmioty widzą Polacy, kiedy zamkną oczy? Jakie obrazy by powiesili w tej sali, wyrażającej ducha swojego czasu? Niekoniecznie musiałyby to być dzieła sztuki, być może przypomniałyby się raczej reklamy, fragmenty dziennika telewizyjnego albo ilustracje $\mathrm{z}$ elementarza? Wchodzą tu $\mathrm{w}$ grę rozmaite kwestie. Jest zagadnienie zasobów intertekstualnych - wiedzy i skojarzeń kulturalnych, które ludzie gromadzą w pamięci przez całe życie. Wydaje się to bardzo istotne.

Gdy się chodziło po wystawie w Royal Academy of Art, łatwo sobie było uświadomić, że te zasoby budowane są poprzez oficjalną edukacje, media i kulturę masową, religię, jest tu też komunikacja komercyjna i polityczna. Wszystko było tu na jednej wielkiej ścianie; ludzie stali, patrzyli i bardzo się cieszyli, że kurator zestawił ze sobą bardzo klasycystyczny portret Nigela Farage‘a i olbrzymią różową panterę. Co każe przywołać zagadnienie splotu mediów i praktyk komunikacyjnych czy edukacyjnych z życiem codziennym ludzi. W tym sensie prywatne jest polityczne i wizualne jest polityczne. Ludzie używają tych obrazów do wyrażania własnych wyborów aksjologicznych. Stają się one częścią osobistej pamięci i treścią praktyk komunikacyjnych, lecz jednocześnie jest też możliwość manipulacji rozmaitymi ważnymi lub atrakcyjnymi obrazami przez różne podmioty 
polityczne czy komercyjne. Wykorzystanie pamięci wizualnej ma więc ogromny potencjał manipulacyjny i ideologiczny.

Ze wstępnej, niewielkiej kwerendy na rodzimym gruncie wiem, że gdy Polaków poprosić o przywołanie najważniejszych dla nich obrazów, pojawia się dziwne materii pomieszanie. Co zatem widzą Polacy, kiedy zamkną oczy? Co podpowiada im wizualna pamięć? Oczywiście zależy to od tego, kiedy się urodzili. Ludzie w pewnym wieku znają Pacmana, inni już kompletnie nie wiedzą co to jest, ale okazuje się, że dla tych, którzy wspominają lata 80., ten Pacman jest czymś, co zakotwicza pamięć o szkole i młodości. „Kucie kos” Grottgera przez lata wisiało w klasach szkolnych, a dziś twórcy scenografii serialu „Klan” wieszają tego Grotgera na ścianie w polskim inteligenckim mieszkaniu, żeby pokazać, że to jest tradycyjna polska rodzina. Więc ludzie mają tego Grotgera w głowach razem z Pacmanem i Hansem Klossem. Matkę Boską Częstochowską widzą prawie wszyscy, nawet zupełnie młodzi. Nawet ci niezbyt religijni uważają ten obraz za bardzo ważny element pamięci wizualnej Polaków o długich korzeniach historycznych. Jednocześnie jednak wiele osób mówiło w ostatnich miesiącach, że to swastyka z wafelków Prince Polo, pokazana całkiem niedawno w reportażu TVN na temat polskich neonazistów pozostanie obrazem, który długo będą nieść pod powiekami. Potencjał aksjologiczny pamięci wizualnej jest ogromny; zapamiętane obrazy wiążą się dla ludzi z mocnymi emocjami pozytywnymi i negatywnymi.

Warto się wstępnie przyjrzeć pierwszej bazie jakichś stu - mniej więcej - obrazów sztandarowych. Inspiracją dla takiej konceptualizacji problemu był projekt badawczy pod kierownictwem prof. Walerego Pisarka „Polskie słowa sztandarowe i ich publiczność”, o niesłychanie istotnych konsekwencjach aksjologicznych. Miał on na celu identyfikację słów, które dla Polaków stanowią miranda i kondemnanda, wywołują natychmiastową pozytywną lub negatywną reakcję aksjologiczną. Podobne badania zrobił też zespół Michaela Fleischera we Wrocławiu. Fleischer pisał o systemie symboli kolektywnych, ale także jego badania dotyczyły przede wszystkim słów. Jest tu ta sama idea - że pewne pojęcia czy słowa wywołują kolektywną reakcję aksjologiczną. Pojawiło się w związku z tym pytanie, czy istnieją wizualne miranda i kondemnanda Polaków, i które z nich mają największe znaczenie dla pamięci i tożsamości zbiorowej Polaków po II wojnie światowej.

Chodzi więc o zestaw polskich obrazów sztandarowych. Mogą to być obrazy o charakterze ikonicznym, indeksującym albo symbolicznym. Dzieła sztuki, 
fotografie, kadry filmowe, ilustracje, reklamy, symbole polityczne i handlowe. Zagadnienie badawcze ma trzy aspekty. Dokumentacyjny, czyli pytanie o to, co pamiętają Polacy. Aksjologiczny - czyli pytanie o to, jak te obrazy są wartościowane, i które $\mathrm{z}$ nich stanowią miranda lub kondemnanda $\mathrm{w}$ dziedzinie pamięci wizualnej. Integracyjny - czyli pytanie o to, które z pamiętanych obrazów przede wszystkim przyczyniają się do podtrzymania kulturalnej wspólnoty w sytuacji ogólnego rozpadu wspólnoty intertekstualnej, zwłaszcza narodowej, pod wpływem mediów społecznościowych, nadmiarowej oferty produktów kulturalnych i ich globalnego obiegu. Jest więc również pytanie, na ile globalna kultura audiowizualna tworzy nam dzisiaj te miranda i kondemnanda, a na ile jest to nasz zasób własny i odrębny.

Problemem przy konceptualizacji zagadnienia jest wydzielenie obrazów z całej struktury codziennych doświadczeń ludzi; stąd nacisk na dzieła sztuki, kadry filmowe, reklamy, ilustracje, plakaty, fotografie. Na wystawie na temat, Stanisława Wyspiańskiego w krakowskim Muzeum Narodowym w 2018 roku, stworzono przestrzeń, w której widzowie mogli proponować obrazy, które utożsamiają z polskością. Okazało się, że ponieważ natura obrazów nie została jasno zdefiniowana, ludzie pokazują np. schabowego z kapustą albo fiata 126p, bo ich zdaniem to jest polskość. Czyli nie tyle odnoszą się do warstwy wizualnej, ile do przedmiotów, do całej materialnej warstwy codzienności. Tymczasem w ewentualnych badaniach nad obrazami sztandarowymi chodzi także o formę; nie tylko o to, co ludzie widzą, kiedy zamkną oczy, ale też jak to widzą. Stąd roboczy podział materiału wizualnego na ikony, indeksy, symbole; wykluczenie natomiast rzeczy, miejsc, osób.

Wobec potencjalnego ogromu ludzkich zasobów pamięci wizualnej, przy ich badaniu konieczne będzie zapewne skojarzenie dwóch metodologii, opartych na wyborze sterowanym i swobodnym. W związku z tym - etap ekspercki i etap ilościowy. Na etapie eksperckim 120 ekspertów - ludzi zajmujących się komunikacją wizualną, sztuką, filozofią, edukatorów, artystów - proponuje zestaw wizualnych mirandów i kondemnandów. Z niego stworzony zostaje podstawowy pierwszy zasób, który posłuży do badań ilościowych nad rozpoznawalnością tych najważniejszych obrazów oraz ich konotacjami aksjologicznymi. Jednocześnie zaś specjalna aplikacja $w$ internecie pozwoli ludziom na samodzielne proponowanie własnych wizualnych mirandów i kondemnandów. W rezultacie powinna powstać wielka baza danych/obrazów, umożliwiająca badania nad różnymi aspektami pamięci 
wizualnej i aksjologii Polaków. Integralną częścią przedsięwzięcia będzie jednocześnie prowadzenie wywiadów, umożliwiających identyfikację źródeł oraz interpretacje wskazywanych przez ludzi obrazów sztandarowych. Tutaj z pomocą mogą przyjść także, bardzo mało u nas stosowane, metodologie arts-informed research, łączące swobodne generowanie sztuki przez badanych ze ścisłą analizą ilościową i jakościową powstałego w ten sposób materiału badawczego.

\section{Dyskusja po referacie prof. Matgorzaty Lisowskiej-Magdziarz}

Michał Dróżdż: Wszelkie badania są godne pochwały. Jaki jest zasadniczy cel tego? Oprócz badania pamięci, zatrzymania ducha czasu, bo to jest chyba główny cel...

Małgorzata Lisowska-Magdziarz: Cel nadrzędny jest podobny jak w wypadku badań Pisarka, który wskazał, że poprzez badanie słów sztandarowych czegoś ważnego się możemy dowiedzieć o nas samych i o tym społeczeństwie. Możemy również zmierzyć się z ogromnym potencjałem manipulacyjnym czy retorycznym niektórych słów. W projekcie profesora Pisarka w każdym kolejnym wydaniu książki pojawiały się różne zaskoczenia, które pokazywały, że czasem nie jest tak, jak nam się wydaje z tymi słowami. Bardzo ciekawe jest na przykład, jak zmiennie interpretowano słowa, które wiązały się z kolektywem i zbiorowością. Drugi cel naszych badań jest węższy: monografia o pamięci wizualnej, sposobach jej konstruowania oraz o jej źródłach w życiu współczesnego człowieka w zmediatyzowanym społeczeństwie. Cel trzeci to odpowiedzi na pytania o miejsce obrazów w życiu prywatnym ludzi, i o splot prywatnego i publicznego. Czwarty - zupełnie aplikacyjny. Dziennikarze, badacze, pedagodzy szukają publikacji, która by im pomogły w zrozumieniu tego społeczeństwa, dostarczyłaby materiału empirycznego na temat jego postaw i wartości. Wyniki tych badań pomogłyby im może w pracy.

Michał Dróżdż: Owoce tego badania można zastosować w wielu sytuacjach, np. ta wiedza - czy będziecie państwo różnicować kategorie wiekowe, bo różnica percepcji wizualnej czy pamięci?

Jarosław Gugała: Mnie się wydaje, że to, co pani profesor powiedziała o rozsypaniu się wspólnoty poprzez zniszczenie tych wspólnych kategorii dla wszystkich, wspólnych obrazów, z tego badania może wyniknąć doskonale. Dlatego że moje pokolenie na pewno wskaże bitwę pod Grunwaldem, a mój syn być może w ogóle nie wie, co to jest bitwa czy Grunwaldem. 
Małgorzata Lisowska-Magdziarz: Dlatego jest ten etap ekspercki i kwestia tego wyboru sterowanego; bo tutaj da się zbudować wielką bazę danych i analizować wyniki przy pomocy technik data mining. To nie będzie polska próba reprezentacyjna 3100 osób, tylko prawdopodobnie większa. Będzie też musiała mieć charakter warstwowy. Kryteriami różnicującymi będą nie tylko płeć i wiek, lecz także choćby wykształcenie czy miejsce zamieszkania. Można na przykład liczyć na to, że w pewnej mierze odrębne zasoby pamięci wizualnej pokażą Ślązacy, a inne Kaszubi.

Michał Dróżdż: Można z tego wyciągnąć bardzo praktyczny wniosek. Jeśli my nosimy jakieś obrazy w pamięci i traktujemy jako sztandarowe, to można je wykorzystać jako nośniki innych wartości przyklejone do innych wartości, np. w reklamie, bo perswazja poprzez obraz utrwalony jest zupełnie innego rodzaju, niż to, co jest wykreowane na potrzeby jakiejś nowej sytuacji.

Małgorzata Lisowska-Magdziarz: Dlatego uważamy to za bardzo ważne, bo nikt tego nie spróbował.

Jarosław Gugała: Mam metodologiczne pytanie. Mnie się wydaje, że może się okazać, że kolaż mojego pokolenia będzie zawierał mnie elementów niż kolaż pokolenia moich dzieci. Ale to nie musi być prawda, bo może się okazać, że młodsze pokolenia mają bardziej rozstrzelone i bardziej różnorodne zainteresowania...

Za moich czasów ja i mój kolega, mieszkający w bloku naprzeciwko mojego, czytaliśmy te same książki, oglądaliśmy te same filmy, śpiewaliśmy te same piosenki. Dzisiaj dwóch chłopaków, mieszkających w bloku na przeciwko siebie, może nigdy nie zobaczyć tego samego filmu, wysłuchać tej samej piosenki, przeczytać tej samej książki... Jednak naturalnym ograniczeniem zdolności percepcyjnych człowieka jest to, że - porównując nas do komputerów - możemy w swojej pamięci operacyjnej mieć tylko określoną liczbę danych i obrazów. Może się okazać, że ten kolaż będzie bardziej zróżnicowany między poszczególnymi uczestnikami tego badania w danym pokoleniu, ale i tak każdy z nich będzie miał tylko tyle, ile jesteśmy w stanie jako ludzie pomieścić.

Teraz coś z telewizyjnej praktyki. Kiedy ja 30 lat temu zaczynałem pracę w telewizji, mówiło się, że najkrótszy element potrzebny przy montażu programów informacyjnych musiał mieć co najmniej trzy sekundy, a tak zwana setka w materiale informacyjnym mogła mieć 25 sekund. Dzisiaj montuje się dużo szybciej. Tnie się częściej niż co trzy sekundy, a setki mogą zawierać dwa słowa, co kiedyś było zupełnie niestosowane. I to potem przekłada się na ogląd i możliwości 
percepcji świata audiowizualnego. Próbowałem moim dzieciom, gdy były małe, puścić ulubiony film mojego dzieciństwa.. Nie były w stanie przebrnąć pierwszej sceny, w której kamera powoli przesuwała się, pokazując jakiś pejzaż, w którym nic się nie działo, aż dojechała do siedzącego nieruchomo na koniu Winnetou. Moje dzieci wyszły, zanim główny bohater pojawił się na ekranie. Ja byłem wkurzony, pytałem, dlaczego nie chcecie tego filmu oglądać? Dla nich tak powolna narracja obrazem była nie do zniesienia. Odbierały ją jako koszmar, czy jakąś torturę.

Filip Bajon: To jest trochę rezultat demagogii, której mass media uległy. Bo to nie jest prawda, że musi być krócej i bardzo krótko, i że to jest lepiej.

Jarosław Gugała: Dlatego to powiedziałem. Chciałem zwrócić uwagę na to, że w tym badaniu może wystąpić podobny problem.

Grzegorz Łęcicki: Pamiętam te wystawy i popieram badanie tego, co jest wspólne - wobec zjawiska rozpadu wspólnoty narodowej, która wynikała m.in. ze wspólnych lektur. To jest niezwykle potrzebne, dlatego że ja już w tej chwili zaczynam widzieć istotne różnice kulturowe wobec pokolenia moich studentów. Oni już nie wiedzą, kto to jest Kapitan Nemo, Winnetou; zaczynamy więc szukać wspólnych obrazów, czyli filmów; najgorzej jest z tym, że trzeba te filmy też im pokazywać, bo nawet ich nie znają.

Małgorzata Lisowska-Magdziarz: Wiadomo że nawet największa baza danych musi mieć swoje granice. Dlatego należy raczej poszukiwać pewnego trzonu, tego co wspólne niż rozbieżności. Dlatego do ekspertów zwracamy się o twardy trzon, a otwarta aplikacja, do której każdy będzie mógł wejść, a od czasu do czasu wygrać jakąś nagrodę, pozwoli na to, by samodzielnie proponować obrazy, które są ważne indywidualnie lub dla wąskich grup ludzi.

Jarosław Gugała: Jeszcze jedna uwaga, bo to jest bardzo istotne w momencie planowania tego badania. Znam badanie, które dotyczyło tzw. osobliwości telewizyjnych. Było w nim pytanie, która z dziennikarek telewizyjnych, z kręgu publicystyki i informacji, jest najbardziej seksi. Z badania wynikało, że najbardziej seksi były te dziewczyny, które były najbardziej znane. Bo takie badanie jest rodzajem egzaminu i ludzie - nie potrafiąc sobie przypomnieć, jak się nazywa ta, która im się podoba - wymieniali te, które znali.

Wojciech Kajtoch: W jaki sposób będziecie później analizować te obrazy? Bo przecież one mają różne elementy i być może tylko niektóre będą miały kluczowe znaczenie przy doborze. No, weźmy np. Madonnę z dzieciątkiem. Przecież 
jeśli ją tylko naszkicować, to jest po prostu matka karmiąca dziecko. Generalnie nie ma chyba bardziej naturalnego obrazu, który by człowiekowi odpowiadał niż matka karmiąca dziecko. To jest oczywiście tylko taka hipoteza, ale właśnie generująca pytanie, jak będziecie ten materiał analizować.

Małgorzata Lisowska-Magdziarz: Dlatego cała idea opiera się na przywołaniu konkretnych obrazów związanych z konkretnym kontekstem komunikacyjnym. Ludzie nie mówią „jakaś madonna”, mówią: „Matka Boska Częstochowska". Jeżeli by spytać, jaki jest najważniejszy obraz religijny, to prawie wszyscy mówią o „Częstochowskiej”, prawie wszyscy starsi ludzie. A niektórzy mówią: „Jest taki obraz z Jezusem na łodzi. On taki długi był, wisiał w sypialniach u ludzi”. To jest takie monidło, które się kupuje do dzisiaj w sklepach z dewocjonaliami, które jest kompozytem z różnych dzieł malarskich. I pewnie jeśli będziemy chcieli zbudować zasób obrazów religijnych, to znajdzie się tam również Jezus łagiewnicki i parę innych. Twardy trzon to jest właśnie to. Ciekawe, że „Matka Boska Częstochowska” jest jakby publiczna, a obraz z „Jezusem na łodzi, co wisiał w pokoju" jest prywatny. On nie wisi w kościołach, ale dla ludzi jest ważną częścią pamięci wizualnej. Dlatego istotny jest etap rozmów, fokusów. Na samym końcu, jeśli się uda, chcemy tych ludzi z różnych pokoleń nakłonić, żeby stworzyli sami kolaże z ważnych dla nich obrazów. I namówić Muzeum Narodowe lub inne, żeby zrobiło wystawę najważniejszych obrazów Polaków i tego, jak Polacy tworzą Zeitgeist art.

Jarosław Gugała: Pani profesor, i już jest błąd metodyczny. Jak my to weźmiemy do domu, to każdy będzie wydziwiał, kombinował, sprawdzał w internecie id. Lepiej żeby to było na czas.

Małgorzata Lisowska-Magdziarz: Mówimy o ikonach, a nie realnych krajobrazach. Chyba że ktoś jest w stanie wskazać konkretny obraz, z autorem itd. To jest to oddzielenie, czy chodzi nam o konkretny plakat lub kadr z filmu, czy o sfotografowany jakikolwiek kotlet schabowy z kapustą.

Anna Gemra: Ja myślę słowami, a nie obrazami. Jedyne, co mam teraz przed oczami, jeśli chodzi o obrazy z dzieciństwa, to Miś Uszatek.

Małgorzata Lisowska-Magdziarz: Oczywiście obrazy wywołują różne doznania synestetyczne. Ludzie, przywołujący obraz kapitana Klosa, zaczynają śpiewać melodię z serialu...

Michał Dróżdż: Niektóre mają potencjał wizualności o wiele dalej posunięty i pamiętają obrazy, niektórzy pamiętają słowa. 
Małgorzata Lisowska-Magdziarz: Badania ilościowe wskazują raczej główne tendencje, tworzą trzon, a ta pewna liczba ludzi, którzy nie są w stanie w ogóle wygenerować obrazu, pozostanie nam na obrzeżach. Podobnie jak na przykład lokalne wcielenia pamięci wizualnej związane np. z regionem albo ściśle pokoleniowe...

Jarosław Gugała: Wskażą to, co wiedzą na pewno i najlepiej, dlatego że to jest bardzo trudne metodologicznie, żeby odróżnić to, co jest rzeczywistością, od tego, co ludzie z siebie wyduszą, bo uznają, że tak powinno być.

Małgorzata Lisowska-Magdziarz: Jeżeli otwieramy aplikację, która będzie rodzajem gry komputerowej po prostu, no to zakładamy, że przynajmniej młodsze pokolenia spontanicznie wywołają ważne obrazy. Natomiast do ludzi ze starszego pokolenia trzeba pójść osobiście, rozmawiać, czasem poprowadzić ich przez proces przypominania sobie.

Jarosław Gugała: To powinny być jakieś filtry antymanipulacyjne.

Małgorzata Lisowska-Magdziarz: Oczywiście. Badania tego typu mają zwykle bardzo starannie przygotowany scenariusz. Wiadomo w jaki sposób rozmawiać, w jakiej kolejności, co można respondentowi powiedzieć i o co go prosić, a o co nie można. Prawidłowe przygotowanie badań powinno zminimalizować niebezpieczeństwo manipulacji.

Anna Gemra: Przyłączę się do tego głosu, bo przypomniały mi się badania, jakie robił i zresztą robi nadal Instytut Książki i Czytelnictwa Biblioteki Narodowej. Jego ankieterzy ujawnili, że w zależności od sytuacji, w jakiej przeprowadzali badanie, otrzymywali różne wyniki w tej samej grupie. Klasyczny przykład: uczniowie pytani w ankiecie o to, co czytają, inaczej odpowiadali, gdy w klasie był nauczyciel, a inaczej, kiedy go nie było. To były dwa całkowicie czasem odmienne zestawy tekstów. Podobnie było też w wypadku osób starszych: udzielały takich odpowiedzi, żeby jak najlepiej wypaść w oczach ankieterów. Uważały też, że takie właśnie odpowiedzi są pożądane. Okazywało się więc, że na przykład do poduszki nie czytują kryminałów, ale Pana Tadeusza. Wbrew pozorom, dzieje się tak i dzisiaj, bo ludzie wiedzą - na przykład ze szkoły - co powinni, a czego nie powinni czytać i oglądać.

Małgorzata Lisowska-Magdziarz: Dokładnie wiadomo co robić, żeby nie doszło do procesu grupowego, wyprzedzania intencji, gdyż są pewne patenty metodologiczne, które mniej więcej wiadomo jak zastosować. Oczywiście nie ma stuprocentowo akuratnych metod, ale w humanistyce nigdy nie mamy pełnej pewności co do ostatecznego charakteru badań. 


\section{Filip Bajon, „Audiowizualność w pracy reżysera filmowego”}

Zastanawiałem się nad tym tytułem i on mi sprawił pewną trudność. No, bo jeżeli aksjologia audiowizualności, to czy mówimy o efekcie, czy o gotowym audiowizualnym dziele, czy też mówimy o aksjologii środków użytych w budowę tego dzieła. Mnie, jako praktyka, interesuje to drugie - ponieważ państwo, jak rozumiem, jesteście od oceniania i badania metodologii postępowania twórcy, a ja to znam, że tak powiem, od podszewki. I zacząłem się nad tym zastanawiać, jakiego typu pułapka tutaj tkwi w tej aksjologii audiowizualności, bo obraz filmowy ontologicznie jest zawsze prawdziwy. Nie ma fałszywego obrazu filmowego, ponieważ to, że to jest obraz filmowy, zaświadcza, że to kiedyś było, że kiedyś zaistniało. W związku z czym widz dlatego wytrzymuje te amerykańskie filmy, trzy sekundy jedno ujęcie, latających Spider-Manów, bo widzi to na ekranie i on w to wierzy, że to kiedyś było. Czyli ontologicznie i, że tak powiem, aksjologicznie obraz filmowy jest prawdą i zawsze będzie prawdą. Aksjologię, w trochę uproszczony sposób, rozumiałem trochę $w$ ramach dobra i zła. Odrzuciłem gdzieś piękno.

Jak ten audiowizualny obraz może być postrzegany w kategorii dobra i zła? Muszę też państwu powiedzieć, jak ja zaczynałem. Byłem w szkole filmowej, robiłem pierwsze filmy itd., kategorii audiowizualność jeszcze nie było. Była tylko kategoria obrazu filmowego. Audiowizualność pojawiła się z nowymi środkami, a więc z końcem analogu i początkiem cyfry. Jak się pojawiła cyfra, pojawiła się audiowizualność. Jak się pojawiły kamery telewizyjne, pojawiła się audiowizualność. Poszerzając w olbrzymi sposób pole, że tak powiem, naszych penetracji. Przecież ja na początku, kiedy pojawiły się kamery filmowe i cyfra, myśmy się wszyscy tym brzydzili. Myśmy tego nie dotykali, bo to było coś obrzydliwego, bo to psuło wszystko, że na tej becie (rodzaj kamery - MF) nie można nic było ładnie nakręcić. Te wielkie kamery telewizyjne były nieruchawe. Bardzo ładnie kiedyś taki montażysta określił różnicę między taśmą cyfrową a analogową. Powiedział tak: „Jak ja widzę na zdjęciu filmowym pusty pokój, to jeżeli jest to zrobione na taśmie filmowej, to ja wiem, że za chwilę ktoś wejdzie. Jeśli jednak jest to zrobione na cyfrze, to ja wiem, że przed chwilą ktoś wyszedł". Świetny opis tego, co się działo.

No, ale teraz, mówiąc o audiowizualności i wszystkich możliwościach, wiemy, że tak naprawdę te pewne środki, które stosujemy, aby stworzyć tę audiowizualność, mogą podlegać manipulacji i mogą być złe. Czyli korzystając z wiary widza, 
że to wszystko, co widzi, jest prawdą, można nim fantastycznie manipulować. Nie mówię jeszcze o manipulacji na poziomie montażu. Mówię na poziomie czystego ujęcia przepuszczonego bądź przez kamerę filmową, bądź przez kamerę cyfrową; bo ja się z cyfrą pogodziłem. I teraz przypomina mi się coś takiego, co widziałem na własne oczy. Będąc w muzeum braci Lumière, widziałem jedne z pierwszych filmów nakręconych na świecie. Były to filmy o takich bato (małych łódeczkach) pływających po Sekwanie. Wszyscy ci ludzie, którzy tam się pojawili, nie byli nigdy w kinie, bo nie mogli być w kinie, bo go jeszcze nie było. To są pierwsze trzy miesiące, kiedy Lumière wyszedł $\mathrm{z}$ fabryki, dworca itd. i wszedł $\mathrm{w}$ tłum. I zaczął ten tłum filmować. Odpowiedzcie mi na jedno pytanie: Dlaczego oni wszyscy bali się kamery? Dlaczego oni wszyscy zasłaniali twarze? Przecież nigdy siebie nie widzieli na ekranie filmowym? Nie znali efektu, a już się bali? Czyli oceniali kamerę filmową z taśmą i efektem aksjologicznie źle? Od samego początku było w tym coś podejrzanego. Mówiąc o tych różnych elementach, czy one są elementami poza dobrem i złem? Ujęcie jest obiektywne. Ale ujęcie można bardzo przedłużyć. Ujęcie można skierować w ten sposób, że się zrobi komuś krzywdę. Dlatego Krzysiu Kieślowski przestał robić dokumenty, ponieważ uznał, że ma w ręku środek, który może zrobić krzywdę. Czyli ten obiektywny środek, ujęcie, może być aksjologicznie zły. Efekt może być aksjologicznie dobry, ale sam środek może być aksjologicznie zły.

Przejdźmy do montażu. Jest słynny esej Andre Bazena o „... kronikach Wermachtu z II wś", gdzie on udowadnia, jak to wszystko zostało skłamane. I to jest później często stosowane - pokazujesz czołgi niemieckie, nie pokazujesz radzieckich. Nie ma tutaj równowagi i wiesz, że Wermacht wygrywa. To są tego typu manipulacje. Ale mogą być jeszcze inne manipulacje rzeczywistością, która ma być sfilmowana. Otóż odbywały się kiedyś dożynki, jeszcze w epoce Gierka. Czujny pierwszy sekretarz, chyba w Tomaszowie Mazowieckim, gdzie miały się odbyć te dożynki, przejechał trasę, którą za 2-3 dni miał przejechać towarzysz Gierek. Trasę, która będzie sfilmowana i która pójdzie w telewizjach, w dzienniku itd. No, i przejechał i się przeraził, bo tuż obok drogi było nieskoszone pole zboża. I wie, że już nie skoszą tego pola. Co oni robią? Przestawiają granicę województwa i przesuwają pole w woj. piotrkowskie. Sfilmowane - prawda? No, prawda. Nikt nie wie, że znak został przesunięty. Rzeczywistość sfałszowana. Wieś Patiomkinowska sfilmowana, każdy uwierzy, że tak wyglądała wtedy Rosja. Drogą, gdzie car jeździł, co było widać. Więc to też jest następny sposób manipulacji. Ja 
mówię tutaj o pewnych środkach audiowizualnych. A czy zmiana obiektywu jest poza moralnością? Jeżeli zmienisz obiektyw, to więcej widzisz albo mniej widzisz. Odbywa się tutaj pewien rodzaj manipulacji rzeczywistością. Ten rodzaj manipulacji został fantastycznie wykonany, jak papież przyjechał do Polski po raz pierwszy, bo przeszli na długie obiektywy, w związku z czym było widać o wiele mniej. W filmie fabularnym jest to decyzja artystyczna. Długość ujęcia, co pokazujesz, w filmie fabularnym, w podstawowej jednostce audiowizualnej; nie mówię tutaj o YouTube czy Internecie, bo moim zdaniem jest to inne filozoficzne i metodologiczne zagadnienie, w którym są elementy audiowizualności, ale nie są one w tak decydujący i mocny sposób jak w filmie.

Użycie w filmie scenografii też może być pewnego rodzaju zafałszowaniem rzeczywistości. Ale będzie to cały czas rzeczywistość bezinteresownie, bo kamera jest bezinteresowna i to, co kamera daje, jest obiektywne. I zawsze będzie obiektywne, czyli jest poza aksjologią. Chyba że będzie zmanipulowane.

I teraz - tych manipulacji jest bardzo dużo. Powołam się np. na utwór audiowizualny, jakim jest TVP info. W jaki sposób ta manipulacja przebiega i w audio, i w obrazie? Już na początku na drodze do utworu audiowizualnego ta aksjologia i ta pewna moralność (czyli dlaczego używamy danych środków i dlaczego używamy środków audiowizualnych) bardzo często w moim pokoleniu była nazywana kwestią wyboru moralnego. Również panowało takie powiedzenie „nie estetyka, tylko etyka".

Wracając do kategorii dobra i zła - pewne środki filmowe, jak montaż czy gdzieś skierowana kamera, szerokość planu, mogą służyć do manipulacji, opowiadania o rzeczywistości czegoś nieprawdziwego. Natomiast piękno jest moim zdaniem pozaaksjologiczne, choć muszę zaznaczyć, że nie zawsze. No, bo jeżeli obejrzymy olimpiadę z 1936 r. zrobioną przez Leni Riefenstahl, to od razu możemy powiedzieć, że jest piękna, że jest fantastyczna. Natomiast znowu ustawienia kamery, kopanie rowów pod kamerę, żeby była z dołu. Żeby dynamizowała i uwznioślała germańskich sportowców skaczących w dal, skaczących wzwyż, biegnących. Żeby znajdowała cechy pomnikowe, no to tutaj znowu aksjologicznie jest to nie w porządku. Oczywiście, miała też miejsce eliminacja czarnoskórych sportowców, biegających wtedy w barwach USA. Więc generalnie piękno jest poza pewną aksjologią, ale uważam, że bardzo często szukam piękna w filmie. Mnie to bardzo interesuje, żeby zobaczyć coś tak, jak nikt tego nie zobaczył. Mnie nie przeszkadza, że jestem sprawdzany, bo czasami mogą się pojawić pewne dwuznaczności 
właśnie natury aksjologicznej, taka walka o estetyczny wymiar może być czasami aksjologicznie podejrzana, co mówię przeciwko sobie - po to skończyłem studia, żeby również umieć myśleć przeciwko sobie.

\section{Dyskusja po referacie prof. Filipa Bajona}

Michał Dróżdż: Jeśli chodzi o aksjologię, to musimy wrócić do ugruntowanych już kategorii metodologicznych. Aksjologia jest pojęciem ogólnym i obejmuje wszystkie wartości. Dzieli się generalnie na dwie kategorie: etykę (jako aksjologię wartości etycznych, gdzie jest prawda, gdzie jest dobro w środku) i drugą, potężną dziedzinę, czyli estetykę (jako aksjologia wartości estetycznych, gdzie główną wartością jest piękno). Więc film, jako nośnik wartości estetycznych, jest jak najbardziej aksjologiczny. Jeśli komunikuje piękno, to nie jest poza aksjologią, gdzie główną wartością filmu jest przekazanie piękna. Jak to się ma do prawdy? Jest trudną rzeczą. Czy narusza jakieś dobro? Wtedy jest już kategoria etyczna włączona. Piękno nie ma nośnika zła. Zatem moje pytanie: dlaczego stwierdza pan, że film, który jest piękny, jest poza aksjologią? Jak on jest w centrum aksjologii, czyli estetyka jako główna wartość.

Filip Bajon: Może moja prywatna metodologia pozwala mi na to.

Michał Dróżdż: To nie jest zarzut. Mamy tak zwaną estetyzację etyki i to jest powrót do Platona, że piękno i dobro, dwie wartości. Mamy w kulturze cały czas estetyzacje etyki, czyli mierzenie dobra przez piękno. Też jest możliwe, no „piękny człowiek" mówimy w sensie dobry człowiek.

Jacek Dąbała: To by było ciekawe, myślę, uzyskać też odpowiedź od pana prof. Bajona, a propos tej prywatności spojrzenia, bo to jest niezwykle intrygujące. Mamy pewne założenia o charakterze estetycznym i etycznym, mówimy o aksjologii i mamy - nie chciałbym przejść do porządku tak lekko - doświadczonego, dojrzałego, wybitnego twórcę, który na to patrzy inaczej.

Filip Bajon: Ponieważ dla mnie, w moim prywatnym języku i moim prywatnym doświadczaniu świata, „Burza” Giorgione’a może być rozważana estetycznie, ale nie aksjologicznie. „Pieta” Michała Anioła czy też pewne obrazy Botticelliego są dla mnie piękne, ale są pozaaksjologiczne. Ponieważ piękno, dla mnie, wymyka się tym kategoriom. Ponieważ piękno jest ruchomym świętem. To, co było piękne - tu już mówiliśmy na ten temat - w latach 20., potem przestało być piękne. Czy historyczne malarstwo, jak przyszedł impresjonizm, popadło totalnie w zapomnienie i nikt o tym nie piśnie $\mathrm{w}$ tej chwili, bo piękny stał się impresjonizm? 
W związku z czym aksjologia, do czegoś co się zmienia, byłaby nieaktualna. A jeżeli ja patrzę na coś, co jest piękne i dla mnie zawsze jest piękne, to moim zdaniem dzieje się to poza dobrem i złem. Natomiast jeśli chodzi o treść, która ulega manipulacji itd., jak najbardziej podlega aksjologii.

Jacek Dąbała: Aha, czyli mamy tutaj takie dualne spojrzenie...

Filip Bajon: Nigdy nie myślałem o aksjologii w kategoriach estetycznych.

Jacek Dąbała: A to jest bardzo ciekawe, bo proszę zwrócić uwagę, że prof. Bajon zarysował coś takiego, jak temporalność, czyli ta ruchomość piękna. Sama temporalność, fragmentaryczność piękna w pewnym momencie, jakby obiektywnym, nie pozwala mówić o pięknie w kategoriach aksjologicznych. Nie mogę mówić o pięknie jako takim, ponieważ ono z istoty swojej jest chwilowe, momentowe, a jak jest momentowe i chwilowe, to nie ma tego ugruntowania obiektywnego... jeśli dobrze rozumiem.

Małgorzata Lisowska-Magdziarz: No, ale piękno jest wartością w sensie aksjologicznym, jakby podstawową... Prawdopodobnie w wypadku dzieła filmowego mówimy raczej o etyce, niż o aksjologii. Myślę na przykład o „Funny games” Hanekego, które są - abstrahując od wartości filmowej - kategoryczną wypowiedzią etyczną filmowca po stronie pewnego zestawu wartości i przeciwko czemuś, co robi niekiedy współczesne kino. Myślę, że to, co pan nazywa prywatną metodologią, odnosi się bardziej do etyki tworzenia dzieła filmowego niż do jego wartościowania aksjologicznego. Uwalnia nas to od kłopotu polegającego na tym, iż pewne dzieła, nakręcone dawno temu, uchodziły niegdyś za niemoralne, niecenzuralne albo szkodliwe. Dzisiaj patrzymy na nie bez oburzenia, podziwiając jednak ich wartości estetyczne. Nie zostają one bynajmniej zdezaksjologizowane. Zmienia się natomiast ich wartościowanie jako wypowiedzi etycznych.

Michał Dróżdż: Pan profesor reprezentuje to, że kategoria aksjologiczna jest kategoria etyczną, a to, co jest poza kategorią etyczną, czyli piękno, jest wartościowane, waloryzowane inaczej. Natomiast w metodologii nauki jako takiej włącza się piękno do aksjologii. Prawda, piękno, dobro stanowią podstawę trzech wielkich dyscyplin: dobro to etyka, piękno to estetyka, a prawda, która nie jest etyką, jest teorią poznania. Prawda jest treścią poznawczą, nie jest kwestią etyczną. Prawdomówność jest kwestią etyczną.

Jarosław Gugała: Ja z punktu widzenia tego, o czym mam mówić później. Filip Bajon poruszył mnie przykładem Leni Riefenstahl, bo to jest taki przykład kiedy maksymalizowane są dwie wartości lub inaczej - wartość, jaką jest estetyka, 
służy antywartości jaką jest propaganda nazistowska, czyli de facto mowa nienawiści, o której mam mówić. I robi się taki demoniczny splot. To jest jak z nożem, którym można ukroić chleb i można zabić człowieka. I teraz powstaje bardzo poważne pytanie, czy wartość, która jest podporządkowana antywartości, nadal jest tą wartością? Czy daje się ją wyabstrahować z tego splotu i podziwiać?

Filip Bajon: Leni Riefenstahl pod koniec życia robiła fotografie nubijskich wojowników. To było poza polityką...

Jarosław Gugała: Robiła też genialne filmy o rafie koralowej.

Filip Bajon: Genialne, no i ci Nubijczycy to już nie była propaganda faszyzmu, tylko propaganda zafascynowania pięknymi ciałami.

Jarosław Gugała: I teraz w tym wszystkim jest element świadomości i czasu. W czasie, kiedy Leni Riefenstahl fotografowała olimpiadę w Berlinie w 1936 r. faszyzm (nazizm) nie dokonał jeszcze zbrodni, których dokonał później. I ona odwoływała się do rzeczy, które uznawała za wartość: siła, piękno ludzkiego ciała, kult tężyzny fizycznej, nawiązanie do antyku w formie posągowości tych wszystkich postaci i to wszystko, cztery lata później miało już zupełnie inny wydźwięk.

Filip Bajon: Ale już wiedziała, że Liberman opuścił Niemcy?

Małgorzata Lisowska-Magdziarz: I zrobiła „Triumf woli”.

Jarosław Gugała: Coś już wiedział, tylko wielu ludzi w tym czasie pewnych rzeczy nie wiedziało. Czy to był cynizm czy ignorancja? No, to jeżeli rozmawiamy z kolei o zbrodniach dokonanych przez komunistów, to te zbrodnie, jako swój fundament, miały pragnienie zbawienia człowieka. Rozsadzenia niesprawiedliwej struktury społecznej, która niszczyła większość ludzi. A zamieniło się to, w swej realizacji, w zbrodnie jakiej ludzkość jeszcze wcześniej nie znała.

I to jest to, o czym mówiliśmy poprzednio, ja troszkę polemizowałem z prof. Łęcickim, że pewne rzeczy trzeba umieścić bardzo mocno w człowieku i w danym momencie. Bo ten sam człowiek w innym momencie będzie te rzeczy inaczej odbierał i one będą dla niego miały inne znaczenie. Weźmy polityczny przykład z mojej działki - Lech Wałęsa i jego domniemana czy prawdziwa współpraca z SB. Dla ortodoksów prawicowych to go absolutnie skreśla - „Bolek” i koniec. Jak na to spojrzymy beznamiętnie, to co my widzimy? 22-letniego chłopaka, który przyjechał ze wsi do Stoczni Gdańskiej, zaangażował się w jakieś polityczne działania, w międzyczasie urodziło mu się dziecko, został aresztowany. Postraszono go, że nigdy więcej dziecka i żony nie zobaczy, i coś mu podsunięto. I on to podpisał. Załóżmy, że podpisał, bo on twierdzi, że nie. Myślę, że nie było w tamtym 
czasie mądrych, którzy by wiedzieli, co można podpisywać a czego nie, bo dopiero w 1976 r. powstała w Polsce opozycja demokratyczna, która po paru latach zaczęła instruować swoich działaczy w takich sprawach. W tym kontekście, w którym był w 1970 roku Lech Wałęsa, nikt nie zakładał, że komunizm upadnie; nikt nie zakładał, że można walczyć z nim metodami, jakimi się posługiwała opozycja demokratyczna i nikt nie wiedział tak naprawdę, co jest w tym sprawdzone, a co nie. I ten 22-letni chłopak musiał się z tym zmierzyć. Malutkie dziecko, żona, on $\mathrm{w}$ areszcie - masz do wyboru: albo podpisujesz, że będziesz siedział cicho, albo idziesz do pierdla i przez 10 lat nie zobaczysz swojego dziecka. Widząc to, my nagle widzimy ten czyn - domniemany, bo nie wiemy, jak było - i pewnie się nigdy nie dowiemy. W tej kwestii każdy musi wybrać swoją prawdę. My widzimy tę sytuację w zupełnie innym kontekście.

Tak samo oglądając film Leni, pokazujący posągowe postaci związane z igrzyskami olimpijskimi, jesteśmy w innym kontekście, kiedy świat cały już wie, do czego to doprowadziło, niż ludzie, którzy oglądali ten sam film w 1936 r. Więc to, w jaki sposób my jesteśmy uzbrojeni w możliwość odbioru danej wartości i znajomość kontekstu historycznego są bardzo ważne.

Filip Bajon: Padam drugi przykład, bardzo podobny - socrealistyczna sztuka malarska. Widziałem taką wystawę „Moskwa-Warszawa”, gdzie bardzo dużo było socrealistycznych obrazów, m.in. ten słynny „Stalin patrzący na piece Magnitogorska". I ta sztuka socrealistyczna, wtedy ewidentnie niedobra, propagandowa, służalcza, czyli etycznie nie w porządku, po latach okazała się, w wielu wypadkach moim zdaniem, wybitną sztuką. Ten obraz Kobzdeja „Podaj cegłę”. Oceniając piękno aksjologicznie, musielibyśmy zmienić aksjologię, a dla mnie aksjologia w sensie opisu świata - powinna być równie trwała, jak oceny moralne czy jak dekalog.

***

\section{Ks. dr hab. Michał Dróżdź, „Produkcja obrazu czy przesłanie wartości - spór o etyczność przekazów audiowizualnych"}

Skoncentruję się na produkcji obrazu świata w przekazach medialnych. Czy żyjemy w prawdziwym świecie czy w sztucznym, wykreowanym? Według tradycyjnej wizji dziennikarstwa media miały rolę odzwierciedlania świata. Dzisiaj ten akcent przesunął się dużo dalej, czyli media uczestniczą w kreowaniu rzeczywistości. Jak 
to się odbywa? Twórca (nadawca) - czy to będzie dziennikarz, czy ktoś inny - nie przekazuje nam obiektywnego sensu, ponieważ sam postrzega świat subiektywnie. Czasem walczymy i kruszymy kopię na temat obiektywizmu, ale przecież każdy z nas postrzega świat subiektywnie i ma do tego prawo. Więc ta treść przekazu medialnego, audiowizualnego nie zawiera obiektywnego sensu, ale dostarcza pewnych elementów odbiorcy, jakby kontekstu interpretacyjnego do odbiorczej kreacji świata. Czyli to, co się może zdarzyć, ta temporalność, o której mówiliśmy. Przekaz oglądany następnego dnia już traci na walorach informacyjnych i oglądając ten sam wywiad, koncentrujemy się zupełnie na czymś innym, bo już pewne rzeczy wiemy. A więc treść jest jednym z kontekstów interpretacyjnych w kreowaniu świata.

Do opisu tego działania, tego procesu medialnego znakomicie mogą służyć pewne modele konstruktywistyczne. To nie znaczy, że ja podzielam ten pogląd. Co mówi konstruktywizm na temat kreowania obrazu świata? Że rzeczywistość jest subiektywną konstrukcją podmiotu opartą na przekazach prawdziwych lub obiektywnych, ale ta rzeczywistość jaką my mamy, jest subiektywną konstrukcją podmiotu. Poznanie realnej rzeczywistości dzisiaj dokonuje się za pośrednictwem mediów. Nie mamy innego dostępu do tego, co się dzieje w Warszawie, w polityce, wielkim świecie - kanałami docieramy przez różne media.

Mamy tutaj pana redaktora, który uczestniczy w dostarczaniu nam pewnej wizji świata. Pytanie - czy nas interesuje, jak jest, czy też nas interesuje pewien obraz, w którym się czujemy dobrze? Obiektywna ocena rzeczywistości kreowanej medialnie jest ograniczona ze względu na niewielki zasięg pozamedialnych kryteriów takich ocen. To, co się dzieje u nas na spotkaniu, gdyby kamera to ujęła, to i tak dla wielu osób będzie nie do sprawdzenia. Tylko my możemy wiedzieć, jak było naprawdę. Mamy możliwość jeszcze jednego czynnika, w którym możemy sprawdzić przekaz? Zasadniczo czegoś takiego nie mamy. Konstruktywizm mówi, że jeżeli korzystamy z informacji o świecie w audiowizualnych przekazach, to ocena etyczna rzeczywistości medialnej o charakterze obiektywnym i uniwersalnym jest niemożliwa ze względu na brak obiektywnych kryteriów takiej oceny.

I teraz jak to się dzieje w mediach, gdybyśmy te założenia konstruktywizmu przełożyli?

Po pierwsze - realna rzeczywistość jest modelowana według zasad mediów. Świat medialny i realność rzeczywistości wzajemnie się przenikają. Czyli mamy rzeczywistość (fakty) i obraz rzeczywistości w mediach. No, i te granice stają się rozmyte - pytanie, co jest realne? 
Po drugie, co jest prawdziwe? To pytanie będzie tak samo ważne. Co jest realne? Na pewno realny jest obraz medialny, ponieważ powstał, jest realny. Czy on jest prawdziwy? To jest wtórne pytanie. Natomiast świat medialny jest realny dziś to jest ogromny dylemat, bo brakuje nam słów. Czy wirtualny świat jest realny? No, jest realny, bo jest. Ale to rozmywa nam tradycyjne podziały, że mamy potencjalne rzeczywistości, których nie ma - mogą dopiero zaistnieć, ale wirtualny świat jest. Jak ekran jest, to widzimy coś na ekranie, a jak go zgasimy, to już tego nie ma. Ale w zapisie gdzieś może być urealnione.

Po trzecie - media oddziałują na sam kształt rzeczywistości. Więc wiele realnych wydarzeń jest dzisiaj od początku inscenizowanych ze względu na możliwość ich prezentacji w mediach. My znamy te mechanizmy i wiemy, że tak po prostu jest. Że coś się wykreuje po to, żeby to pokazać. Taka sytuacja - dziennikarz stoi w wielkiej wodzie i mówi o dramacie powodzi, ale jednak kamera się gdzieś lekko opuściła i widzimy, że dziennikarz stoi w małym bajorku, a dookoła jest wszystko suche. Jednak obraz, jaki transmitowano, był obrazem wielkiej wody, który został wykreowany na potrzeby dramatyczności sytuacji. Czyli media kształtują realny stan rzeczywistości poza medialnej, która jest coraz bardziej przesiąknięta elementami medialności. Wiemy, jak to jest w przekazie politycznym.

Po czwarte - media zmieniają uwarunkowania czasowo-przestrzenne realnego życia. Ponieważ przestrzeń i czas stają się względne w tym wszystkim. I albo tworzymy coś ze względu na czas, czyli mówimy, że to jest „live” i musimy zaznaczyć, żeby widz wiedział, że to jest naprawdę tu i teraz. A jak nie zaznaczymy, to mamy wątpliwości, czy to rzeczywiście jest tu i teraz. I podobnie jest również z przestrzenią.

Piąte - granica między realnością a symulacją. Wiemy, jak to wygląda w technologii przekazu telewizyjnego, że mamy tam mnóstwo rzeczy generowanych z komputera i nakładanych na realny obraz studia. Widz wcale nie wie, nie rozróżnia tego, czy stół jest wirtualny, czy stół przy którym siedzą goście nałożony jest z elementów z tricastera. Cała inscenizacja jest wykreowana w sposób sztuczny. A widz ma poczucie, że widzi realny świat, realną dekorację.

I jakie są tego konsekwencje? Może jeszcze przejawy tej mediatyzacji, tej rzeczywistości wykreowanej? Przekaz audiowizualny produkuje sens, taki jaki chce. My nie możemy czasem idealizować, mówić, że mamy do czynienia z przekazem prawdziwości, obiektywnych, ponieważ mamy obraz rzeczywistości wykreowany poprzez konkretne media. Jeśli matryca, wedle której tworzy się obraz 
rzeczywistości, jest prawdziwa, jest tak skonstruowana, żeby nie fałszować rzeczywistości, to ten obraz, jaki będzie docierał do widza, będzie obrazem w miarę oddającym rzeczywistość. Jeżeli w matrycy już ukryjemy pewne elementy manipulacyjne, bo albo skrócimy dystans, albo przybliżymy, albo szczegół wypunktujemy, albo pewnymi słowami podkręcimy dramaturgię, wszystko jest możliwe.

Drugim elementem jest kwestia uśredniania opinii, zachowań, postaw odbiorców i oddziaływanie na odbiorców tymi samymi obrazami, hasłami, ideami. Można np. wyprodukować pewne hasła jak „mowa nienawiści”, o której pan redaktor powie. Wydaje mi się, że to jest już pojęcie, które można znakomicie wykorzystywać jako oręż polityczny - czy to z jednej, czy z drugiej strony. Jak się kogoś nie lubi, można po prostu zastosować mechanizm „mowa nienawiści”. Podobnie z kategorią „postprawdy”, a sama definicja ze słownika oksfordzkiego oznacza, że mamy przewagę subiektywnych wizji świat, nacechowanych emocjonalnością.

Na tym polega siła obrazu i oddziaływania, że on jest subiektywny i emocjonalny, bo bez tego po prostu nie da się tworzyć obrazu o charakterze obiektywnym i jest jakiś realizm nie do wykonania. Czyli nie można się zżymać i krytykować tego, że jest bardzo dużo subiektywności w dzisiejszym świecie przekazów audiowizualnych, bo łatwość przekazu dzisiaj, dostępu do sfery publicznej przez Internet, sprawiła, że ludzie udostępnili swoje wizje świata, poglądy, oceny, opinie w nieporównywalny sposób i my chcemy przyłożyć do tych opinii kategorię prawdy. To jest nieuprawnione w tym wypadku. Kategoria prawdziwości przysługuje tylko twierdzeniom, a nie opiniom, poglądom i naszym ocenom. Każda opinia, tutaj potwierdzę to, co pan profesor powiedział, każdy obraz jest stworzony przez kogoś i jest nośnikiem jakiś wartości i jest nośnikiem piękna, jest prawdziwy. Bo powstał, bo po prostu jest i nie można mówić, że go nie ma. Tak samo każda opinia, jaka powstaje, jest prawdziwa, bo ktoś ją wytworzył, „ja tak myślę”, ale czy to, o czym ja myślę, jest zgodne z rzeczywistością, to jest inna sprawa. I dopiero wtedy możemy zastosować kategorię prawdy.

Często w etyce dziennikarskiej mówi się o tej drugiej ważnej kategorii, jaką jest uczciwość. Inaczej mówiąc: moja subiektywność ma granice w uczciwości. Czyli jeśli ja moim subiektywnym obrazem świata przekazanym w treściach fałszuję rzeczywistość, to jest to nieuczciwe i już nie odpowiada standardom prawdy generalnie rzecz biorąc. jeśli my zakwestionujemy kategorię prawdy, to nie mamy żadnej innej kategorii wartości, co do której moglibyśmy się odnieść w ocenach naszych. Ja się zgadzam, że poznanie prawdy, to co my poznajemy, jest jak 
najbardziej subiektywne i o tyle moje poznanie prawdy będzie miało sens, jeśli będzie odzwierciedlać to, co ja poznaje. Czyli jeśli myślę, że na Marsie żyją ludzie, to ja sobie tak mogę mówić, ale jeśli da się to stwierdzić w jakikolwiek sposób, że tam nie ma ludzi, to mój pogląd już jest fałszywy. Do momentu kiedy nie da się pewnych rzeczy zweryfikować, to do tego momentu poglądy mogą funkcjonować.

Jakiś czas temu brałem udział $\mathrm{w}$ dyskusji w Warszawie u pana Grzegorza Łęcickiego. Pojawiło się takie pytanie odnośnie pomnika ks. Jankowskiego. Wtórne jest pytanie dla wszystkich: „Jak było naprawdę?”. Ktoś powiedział, że z punktu widzenia prawnego nie ma żadnych, po jednej czy po drugiej stronie, rozpoczętych procedur formalnych, czyli ani nie wpłynęło formalne oskarżenie do egzekutywy prawnej, ani nie wpłynęło formalne oskarżenie do egzekutywy kościelnej. Ale to już jest wszystko post factum. Ludzi już nie interesuje to, że to są pewne obrazy tego, co poszło w mediach. Jeśli prawdą jest również to, że pan Sekielski do swojego filmu specjalnie konstruował obalenie pomnika i ta sama ekipa następnego dnia przewoziła i postawiła pomnik, po to żeby również ta sama ekipa go rozebrała z powrotem. To po co go ustawiano na dwa dni tylko, żeby mógł postać, skoro i tak wiadomo było, że on będzie rozebrany? To jest przykład tego, jak bardzo realna rzeczywistość jest medialnie połączona, że pewne działania realne, są tak naprawdę zdeterminowane czy wyznaczone przez cele medialne.

Przejdę do etyki - czy w epoce sztucznych światów, czyli tych wykreowanych w rzeczywistości medialnej, są jakieś konteksty etyczne?

Po pierwsze, pluralizm aksjologiczny - człowiek ma prawo do swojego porządku wartości. Mamy też różnorodne kryteria wartościowania, różnorodność form, treści, kontekstów, granic przekazów medialnych. Czy i w jakim stopniu ta różnorodność może i powinna być postrzegana jako bogactwo poznawcze, aksjologiczne człowieka i bogactwo kultury? A pluralizm jako również różność dyskursów aksjologicznych? Nie ma w tym punktu wspólnego. Stawiam tezę, z którą można dyskutować, że o tyle ta różnorodność, czasem może sprzeczność w pewnych ocenach, może być bogactwem, jeśli te wszystkie oceny gdzieś się spotkają w jakimś punkcie wspólnym? Ten punkt wspólny widzę w szacunku i godności dla człowieka, zarówno w jego subiektywnym, jak i obiektywnym rozumieniu. Czyli jednak nie można przekroczyć granic takiego dobrego smaku, przyzwoitości, elementarnego szacunku dla godności człowieka. To powinno być wspólne wszystkim, którzy mają w różnym stopniu wartościowania. 
Po drugie - tego typu kreowanie świata przez twórców nie służy odbiorcy w żaden sposób, ponieważ mu się dostarcza przetworzona papkę. Utrwala się postawy konformizmu, lenistwa intelektualnego, również spirali milczenia wtedy, kiedy te przekazy nie korespondują z moim światem wartości, w którym czuje się dobrze. Przykładem tego, że człowiek w takim świecie żyje i może żyć dobrze, jest ciągle się utrzymująca na wysokim poziomie popularność tabloidów. Co więcej, inne media poważne swoją atrakcyjność przekazu uzyskują poprzez jego tabloidyzację.

Po trzecie, człowiekowi i jego dobru służy szukanie takich form, które są łatwe w odbiorze. Formuła zabawy - czy to rzeczywiście jest dobra droga, żeby człowiek mógł intelektualnie i duchowo się rozwijać?

Po czwarte, czy w tych sztucznych światach nie tracimy takiej możliwości realnego komunikowania się ludzi między sobą? Bo mówi się, że młodzież znakomicie się kontaktuje ze sobą poprzez media społecznościowe, cały czas coś piszą, ale tracą kompetencje komunikowania międzyludzkiego w realnym świecie.

\section{Dyskusja po referacie prof. Michała Dróżdża}

Filip Bajon: To ostatnie stwierdzenie ks. profesora, jest z moich obserwacji, a obserwuje młodzież, mam synów, kolegów, przyjaciół itd. Oczywiście jest to specyficzne środowisko inteligenckie, ale nie zauważam tego typu oddalenia, w ogóle nie mam wrażenia, że oni żyją w innym świecie.

Małgorzata Lisowska-Magdziarz: Badania empiryczne też tego nie potwierdzają, to jest bardziej publicystyczne...

Michał Dróżdż: Ja bym się nawet zgadzał z tą opinią, bo może na wyrost rzeczywiście to wziąłem, gdyż często w sposób powierzchowny się zaczyna to oceniać. Wydaje mi się, że smartfony spełniają znakomitą rolę wspólnototwórczą bardziej, niż nam się wydaję. Nawet gdy siedzą skoncentrowani, to oni są z ludźmi w innym świecie. W innej wspólnocie. Może nie tu i teraz z nami, ale z kimś innym są.

Małgorzata Lisowska-Magdziarz: Cała kultura partycypacji potwierdza to, że człowiek ma ewolucyjną potrzebę komunikowania się z innymi ludźmi i żadne urządzenie techniczne dotychczas mu w tym nie przeszkodziło. Turing mówił, że jak coś myśli inaczej niż my, to nie znaczy, że to nie myśli. Zmieniają się formy...

Natomiast ja, Michale, z całym szacunkiem, zastanawiam się nad zadaniami filozofa w tej naszej trudnej sytuacji ludzi siedzących w bańkach informacyjnych, w których lęgnie się postprawda i hate speech. Bo ty, wykazując dużą tolerancję 
i wyrozumiałość filozofa, powiedziałeś o przekazie audiowizualnym, że on jest jak kot Schrödingera, który jak siedzi w pudełku, to jest martwy i żywy jednocześnie. I dopiero jak otworzymy pudełko, to okazuje się jak jest, czyli przestaje być jednocześnie żywy i martwy. Każdą rzecz możemy uznać za prawdziwą z racji istnienia jej reprezentacji audiowizualnej, jak długo nie sprawdzimy, że jej nie ma. Mnie się jednak wydaje, że filozof, który nie walczy z takim myśleniem, powiedziałabym, kapituluje. Bo wchodzimy w tej chwili w taką technologię, którą w medioznawstwie nazywamy postfotograficzną czy postfilmową.

To, co pan Bajon zechciał powiedzieć o filmie, że coś „zostało sfilmowane, ponieważ istniało", było prawdą w momencie, w którym istniał indeksujący stosunek czy metonimiczny pomiędzy tym, kto stoi za kamerą, a tym, co stoi przed kamerą. Czyli nie można było sfotografować albo sfilmować niczego, co realnie nie stało na wprost aparatu lub kamery. W tej chwili żyjemy w takiej kulturze, w której cała trasa koncertowa Amy Winehouse, zatytułowana adekwatnie Hologram, została zaplanowana w taki sposób, że będą olbrzymie koncerty z udziałem tysięcy widzów, a na scenie Amy Winehouse, która jak wiadomo, nie żyje już dawno - i będzie to wyglądało, jakby ona stała przed tymi ludźmi we własnej osobie. Nigdy jej tam nie było, ani nawet nie została w ten sposób sfilmowana w innej sytuacji, jej postać będzie więc trochę symulacją, ale głównie symulakrum. Będzie miała relację jedynie do obrazów Amy Winehouse, a nigdy do niej żywej. Jeśli przyjmiemy do wiadomości, że kot Schrödingera siedzi w pudełku i my odmawiamy narzucenia mu roli żywego albo martwego tylko dlatego, że oto go właśnie widać, to powstaje grunt dla całego tego irracjonalizmu informacyjnego, który w tej chwili jest. W którym można było na przykład doprowadzić do Brexitu, odwołując się do trzech milionów ludzi, którzy nigdy nie głosowali, ale dostali na swoje konta internetowe miliard postów, wszystkie były nieprawdziwe, ale nakłoniły ich do głosowania. A to dlatego, że status czegoś, co zostało wygenerowane metodami cyfrowymi, jest szalenie kuszący. Zwłaszcza, gdy na domiar złego opiera się na modalności filmowej lub fotograficznej, którą wyuczyliśmy się traktować jako zaświadczającą o prawdziwości obrazu.

Mam świadomość istnienia technik manipulacji obrazem, ale gdy widzę fotografię, to raczej jej wierzę, niż zastanawiam się, czy nie wytworzono jej od początku cyfrowo, bez materialnego odnośnika. Filozof, który mówi, że musimy się z tym pogodzić, kapituluje w zasadniczy sposób. Status ontologiczny technologicznie wytworzonego obrazu to jedno, a prawda to drugie. 
Michał Dróżdż: Filozofia się po prostu nie zajmuje tym i to jest mój ból. W sensie takim, że cały czas młóci Kanta i przeszłość zamiast wyjść na przeciw tego, co się dzieje tu i teraz. Zmiana form poznania rzeczywistości, zmiana statusu rzeczywistości, zmiana uwarunkowań prawdziwości w ogóle, zmiany w kontekście wartościowania rzeczywistości, kiedy mamy nakładające się rzeczywistości realnego świata. Nawet gdyby przyjąć, i to jest moim zdaniem przykład jak najbardziej słuszny, jak można w sposób sztuczny, medialny, zmienić tak realną rzeczywistość, jaką jest Brexit. Wystarczyło medialnie wyperswadować, fałszywie pewnej grupie ludzi decyzję i mamy konsekwencje w realnym świecie o charakterze wiekopomnym. Filozofowie nie będą się z tym zgadzać, ale wydaje mi się, że za wolno reagują na zmiany cywilizacyjne i technologiczne. Nie wychodzą na przeciw, żeby pomóc, dostarczyć pewnych narzędzi. Tak żeby można się było odnaleźć łatwiej w ocenianiu rzeczywistości, w kategoryzowaniu prawdy.

Małgorzata Lisowska-Magdziarz: Pozwoliliście przyjąć do wiadomości, że każdy siedzi na swojej prawdzie.

Anna Gemra: W dalszym ciągu nie dotyka się u nas czegoś takiego jak etyka $r z a ̨ d u$, która w Stanach się fenomenalnie rozwija. Zajmuje się tym między innymi ośrodek w San Francisco. Mają duże projekty poświęcone temu, w jaki sposób media komunikują politykę. Wchodzi w to na przykład kwestia Brexitu. Są sugestie, w jaki sposób powinny reagować na ten fakt media i etycy mediów. W Europie i w Polsce takich projektów i studiów nie ma, a próba wypromowania podobnego myślenia o etyce rządu i polityki w ogóle to jak przebijanie się nie przez szklaną ścianę, ale betonowy, zbrojony słup.

Michał Dróżdż: Jeszcze do pana redaktora - media mają prawo tworzyć obraz rzeczywistości jak uważają, że on odzwierciedla rzeczywistość.

\section{Małgorzata Lisowska-Magdziarz: Naprawdę?}

Michał Dróżdż: Mają prawo tworzyć obraz rzeczywistości taki, żeby jej nie fałszował i mamy dlatego spektrum ocen - jeżeli zaczyna się rzeczywistość fałszować, ale okazuje się, że to zaczyna nie przeszkadzać ludziom, że mamy w Polsce trzy narracje lub dwie narracje główne i jedną środkową, z szacunkiem dla pana redaktora, który się tytułuje w tej chwili najbardziej optymalnym w przekazie dziennikarskim czyli Polsat. I teraz mamy dwa skrzydła skrajne - i mamy takie trzy narracje, które odpowiadają pewnym potrzebom ludzi i wszyscy są zadowoleni. 
Małgorzata Lisowska-Magdziarz: Mnie zawsze interesowały implikacje etyczne takiego zjawiska, ponieważ jest tak: analogowe media, prawdziwy analogowy przekaz = plus, analogowe media i przekaz fałszywy nieprawdziwy, kłamliwy $=$ minus. Cyfrowe media użyte do obrazu fałszywego = minus. Jednak cyfrowe media, które generują obraz świata, pomimo że on nie ma indeksującej relacji czy metonimicznej do rzeczywistości, tylko został wytworzony od razu z matrycy = plus czy minus?

Michał Dróżdż: Zasada logiki mówiła tak: prawda-fałsz, jakie są relacje? Że z prawdy nigdy nie może wynikać fałsz, to jest sylogizm logiczny od starożytności, ale dzisiejsze media ten sylogizm odrzuciły. Że z prawdy może wynikać fałsz. Z prawdziwych obrazów nakręconych można stworzyć fałszywy przekaz o rzeczywistości.

Małgorzata Lisowska-Magdziarz: No, ale czy można z nigdy nienakręconych obrazów stworzyć przekaz, który uznamy za prawdziwy?

Michał Dróżdż: Ale z fałszu - logika dopuszczała i to jest prawdziwy sylogizm - może wynikać prawda.

Wojciech Kajtoch: Tak mi wpadło do głowy: Czy naprawdę w medioznawstwie rozpatrującym tego typu kwestie powinniśmy się trzymać determinizmu technologicznego? Bo przecież ta sytuacja, kiedy nagle olbrzymie grupy ludzi zaczynały wierzyć w coś, w co w zasadzie nie powinny...

Małgorzata Lisowska-Magdziarz: ...że Ziemia jest płaska.

Wojciech Kajtoch: Od tylu, tylu lat... można powiedzieć, że to się zaczęło w momencie, w którym powstała wielkonakładowa prasa. Wtedy nagle np. uwierzono w rasy. Potem te wszystkie doświadczenia wojenne, przecież to była propaganda robiona radiem, gazetą... A jak niesamowicie była skuteczna! Tak więc ludzie żyją w światach fikcyjnych, jak sądzę, od czasu wynalezienia pisma. Tylko że ta ilość ludzi najpierw była mała, potem się zwiększała. Więc czy nie dotykamy bardziej jakiejś właściwości ludzkiego umysłu niż mediów.

Filip Bajon: Czytałem ostatnio książkę o Humboldcie, podróżniku, wielkim naukowcu. Co wynikło poza głównym tematem? Otóż moje zdziwienie, że na początku XIX wieku najważniejsi ludzie na świecie znali się osobiście. Humboldt znał prezydenta USA, z Goethem jadał obiady, znał cesarza Niemiec, znał premiera Anglii.

Jarosław Gugała: Wynikałoby z tego, że w tamtej epoce profesorów UJ-otu, których warto było znać, było dwóch, a dzisiaj jest 150 . 
Koniec części pierwszej sprawozdania.

Udzielam licencji do eksploatacji praw autorskich do przesłanego utworu na zasadach licencji Creative Commons Uznanie autorstwa - Użycie niekomercyjne Bez utworów zależnych 4.0 Międzynarodowe (CC BY-NC-ND 4.0).

Mateusz Flont

ORCID: 0000-0003-1509-4815 